Adam Wielomski

DOI: http://dx.doi.org/10.12775/SEI.2017.002

Uniwersytet Kardynała Stefana Wyszyńskiego w Warszawie

\title{
Suwerenność państwa w stosunkach międzynarodowych w doktrynie Roberta Bellarmina
}

(State sovereignty in international relations in the doctrine of Robert Bellarmin's)

\begin{abstract}
Respublica Christiana (also referred to as Christianitas) is a Pan-European religiopolitical project of the medieval Europe, having claims for universal power upon the whole world being converted into the faith in the resurrection of Jesus Christ. That is a great medieval dream about the theologicopolitical unity about which Jan Baszkiewicz once wrote that it has never materialized. This opinion we do not side with and we hold on to the position that the dream did indeed materialize - even if for a moment - during the pontificate of Innocent III in 1214-16 when, upon the French defeating the emperor Otto IV at the battle of Bouvenies, what was genuinely united in the pontifical hands were the highest religious and political powers.
\end{abstract}

Keywords: Christianitas, sovereignty, Innocent III, Otto IV, international studies, Bellar$\min$

\section{Państwo a uniwersalizm chrześcijański}

\section{Narodziny Lewiatana}

Respublica Christiana, Christianitas to paneuropejski projekt religijno-polityczny mediewalnej Europy, mający roszczenia do władztwa uniwersalnego po przyszłym nawróceniu całego świata na wiarę w Zmartwychwstanie Chrystusa. Oto wielki średniowieczny sen o jedności teologiczno-politycznej, o którym Jan Baszkiewicz napisał kiedyś, że nigdy się nie urzeczywistnił ${ }^{1}$. Z poglądem tym nie zgadzamy się i stoimy na stanowisku, że marzenie zostało zrealizowane, chociaż dosłownie na moment, za pontyfikatu Innocentego III w 1. 1214-16, gdy, po rozbiciu cesarza Ottona IV przez Francuzów pod Bouvines, w ręku pontyfikalnym autentycznie zostały zjednoczone najwyższe władze religijne i polityczne ${ }^{2}$.

\footnotetext{
${ }^{1}$ J. Baszkiewicz: Państwo, rewolucja, kultura polityczna. Poznań 2009, s. 289-93.

${ }^{2}$ A. Wielomski: Teokracja papieska 1073-1378. Myśl polityczna papieży, papalistów i ich przeciwników. Warszawa 2011, s. 188.
} 
Jan Baszkiewicz ma rację w tym znaczeniu, że mit polityczny Christianitas nie został zrealizowany w sposób trwały. Stało się tak z tej racji, że ciało polityczno-religijne Christianitas zawsze miało 2 głowy - cesarską i papieską - a jak słusznie wykładali nowożytni legiści nauczający o władzy suwerennej, żadna struktura polityczna nie może być zarządzana równocześnie przez 2 konkurencyjne a równe sobie ośrodki, bowiem suwerenność jest „równie niepodzielna jak punkt w geometrii”’ Sporne terytorium musi zostać albo podzielone, albo jedna ze stron zdobędzie władzę zwierzchnią. Gdy ludzie Średniowiecza spór imperialno-pontyfikalny postrzegali jako walkę 2 równoprawnych potęg religijno-politycznych wewnątrz Kościoła ${ }^{4}$, to - wbrew intencjom obydwu stron - zakończył się on ideą wyodrębnienia od siebie Kościoła i państwa, co zapowiadało nowożytny rozdział tych 2 instytucji ${ }^{5}$. Zanim myśl taka pojawiła się, to przez kilka stuleci obserwujemy walkę papieża i cesarza o supremację i zjednoczenie pełni władzy nad Europą. Wielusetletni konflikt skończył się zwycięstwem Kościoła, gdy Innocenty IV pokonał ostatecznie cesarza Fryderyka II, a po jego śmierci (1250) w cesarstwie na 23 lata zapanowało bezkrólewie, w czasie którego niemieccy feudałowie zdobyli tyle niezależności i swobód, że (ułomne) zjednoczenie dawnej Rzeszy nastąpiło dopiero w 1870 roku, czyli po 620 latach.

Zwycięstwo papieskie okazało się pyrrusowe. W czasie konfrontacji potęg cesarskiej i papieskiej, obydwie strony szukały poparcia w konsolidujących się monarchiach narodowych i strukturach terytorialnych. Szukając poparcia książąt niemieckich cesarz Fryderyk II dokonał samo-zrzeczenia się wielu prerogatyw monarszych na ich rzecz, co czyniło jego uniwersalną władzę iluzoryczną, skoro faktycznie utracił kontrolę nawet nad obszarami niemieckojęzycznymi, byle tylko, na krótką chwilę, dokonać maksymalnej mobilizacji politycznej dla zdobycia Italii i pokonania papieża ${ }^{6}$ Z kolei Kościół katolicki wzmacniał wszelkie ruchy emancypacyjne lokalnych władców od władzy cesarskiej ${ }^{7}$, szczególnie we Francji, której rosnąca potęga militarna w decydującym momencie przechyliła szalę zwycięstwa w zmaganiach o Europę na rzecz Innocentego III. Aby uzasadnić prawo Francuzów do walki z wojskami cesarza - nominalnego zwierzchnika wszystkich

${ }^{3}$ C. Le Bret: De la souveraineté de Roy. Paris 1689 [1632], s. 19.

${ }^{4}$ M. Garcia-Pelayo: El Reino de Dios. Arquetipo politico. Madrid 1959, s. 101-87.

${ }^{5}$ Ibidem, s. 213-14; B. Töpfer: Tendenzen zur Entsakralisierung der Herrscherswürde in der Zeit des Investiturstreits, „Jahrbuch für Geschichte des Feudalismus“, 1982, nr 6, s. 163-72.

${ }^{6}$ Przywilej Fryderyka II dla książąt niemieckich z 1232 roku. [w:] B. Lesiński, J. Walachowicz: Historia ustroju państwa w tekstach źródłowych. Warszawa-Poznań 1992, s. 32-33.

${ }^{7}$ F. Calasso: I glossatori e la teoria della sovrenità. Milano 1951, s. 22-37; A. Prieto Prieto: Inocencio III y el SacroRomano Imperio. Leon 1982, s. 204-11. 
władców chrześcijańskich - papież musiał ogłosić brak podległości królów Francji wobec władzy imperialnej. Dlatego Innocenty III wygłosił słynną formułę, że król Francji „nie uznaje nikogo nad sobą w kwestiach doczesnych" (rex ipse superiorem in temporalibus minime recognoscat) $)^{8}$. Jakkolwiek kanoniści tłumaczyli, że w stwierdzeniu tym chodziło wyłącznie o podległość wobec cesarza, a nie wobec papieża9 , to w Paryżu udano, że interpretacja ta nie dotarła nad Sekwanę. Skutki narodzin suwerennej monarchii francuskiej ujawnił spór Bonifacego VIII z Filipem IV Pięknym na początku XIV stulecia, zakończony próbą porwania papieża w Agnani (1303), w wyniku którego papiestwo przegrało walkę o panowanie nad Europą na rzecz państw narodowych. Nawiązując do znanej nam już sentencji Innocentego III, zwycięski król Francji pisze:

Kierownictwo kwestiami doczesnymi królestwa przynależy tylko do króla i do nikogo innego i nie uznaje on nikogo nad sobą, jak i nie ma zamiaru poddać się i ograniczyć komukolwiek co do kwestii doczesnych w swoim królestwie ${ }^{10}$.

W literaturze przedmiotu, szczególnie starszej, nie brak opinii, że państwo suwerenne istniało de facto już w głębokim Średniowieczu, acz bez odpowiedniego języka prawno-politycznego ${ }^{11}$. Dopiero wzmacniające się pod koniec Średniowiecza struktury terytorialne zaczynają kształtować nowy język prawno-polityczny. Pojawiają się terminy państwo oraz suwerenność, które nie istnieją w mediewalnej łacinie ${ }^{12}$. Pod koniec epoki pojawia się suwerenne państwo i jego polityczna formuła w postaci monarchii narodowej ${ }^{13}$.

\footnotetext{
${ }^{8}$ Innocenty III: Regestorum sive Epistolarum. [w:] Patrologia Latina. Paris 1848-49. T. CCXIV, V, 128 (kol. 1132).

${ }^{9}$ G. de Lagarde: La naissance de l'ésprit lä̈que au déclin du Moyen Age. T. I. Paris 1942, s. 162-63; S. Mochi Onory: Il tramonto della sovranità imperiale, "Rivista di Storia del Diritto Italiano", 1951, nr 24, s. 174; S. Panizo Orallo: Persona juridica y ficción. Estudio de la obra de Sinibaldo de Feischi (Inocencio IV). Pamplona 1975, s. 80. ${ }^{10}$ Cyt. za: M. Pacaut: La Théocratie. L'Eglise et le pouvoir au Moyen Age. Paris 1957, s. 189.

${ }^{11}$ M. David: La souveraineté et les limites juridiques du pouvoir monarchique du XIe au XVe siècle. Paris 1954, passim, szcz. s. 13-86; J. Baszkiewicz: Państwo suwerenne w feudalnej doktrynie politycznej do początku XIV wieku. Warszawa 1964, s. 8n, 31n. M. David (op.cit.) wylicza pojęcia, którymi mediewalni prawnicy i politycy starają się opisać państwo i jego suwerenność (s. 33-48). Problem pojęciowości suwerennego późnego państwa mediewalnego omawiają także C.N. Sidney Woolf na przykładzie włoskiej nauki prawa (Bartolus of Sassoferato. His Position in the History of medieval political Thought. Cambridge 1913, s. 142-43, 154-70), a przede wszystkim L. Sanchez Agesta w znakomitej rozprawie napisanej na podstawie hiszpańskiej nauki prawa (El concepto del Estado en el pensamiento español del siglo XVI. Madrid 1959, s. 65-111).

${ }^{12}$ M. David: La souveraineté et les limites..., s. 72-80; H. Quaritsch: Souveränität. Entstehung und Entwicklung des Begriffs in Frankreich und Deutschland vom 13. Jahrhundert bis 1806. Berlin 1986, s. 13-28; Q. Skinner: The State. [w:] T. Ball, J. Farr, R.L. Hanson (red.): Politicial Innovation and Conceptual Change. Cambridge 1989, s. 93n.; J. Bartelson: A Genealogy of Sovereignty. Cambridge 1996, s. 88-89.

${ }^{13}$ G. de Lagarde: La naissance de l'ésprit..., t. I, s. 123-29; G. Post: The Theory of public Law and the State in the thirteenth Century, "Seminar", 1948, nr 6, s. 417-32; W. Ullmann: The Development of the medieval Idea of Sovereignty, "The English Historical Review", 1949, nr 1, s. 1-33; M. Wilks: The Problem of Sovereignty in the Later Middle Ages: the Papal Monarchy. Cambridge 1963, s. 433-51; J.B. Morall: Political Thought in medieval
} 
Dla uniwersalnej monarchii pontyfikalnej nie ma miejsca pośród nowo kształtujących się podmiotów w stosunkach międzynarodowych, gdyż na 1 terytorium nie może panować równocześnie 2 suwerenów: lokalny władca i suwerenny pontifex Rzymu.

Po klęsce projektu Christianitas za Bonifacego VIII, Kościół zaczyna przegrywać i cofać się w konfrontacji z państwem terytorialnym. Porażka w starciu z Francją spowodowała uzależnienie Rzymu od Paryża, pogłębione przez przejęcie przez Andegawenów panowania nad południową Italią, co przeważyło szalę większości na korzyść francuskich kardynałów na kolejnych konklawe. W 1305 roku na papieża wybrano abpa Bordeaux jako Klemensa V, który obsadzał kolegium kardynalskie wyłącznie Francuzami i ich sprzymierzeńcami. Jego następcy, wybierani przez większościowe francuskie gremium, formalnie przenieśli stolicę Kościoła do Avignonu, uznając protektorat francuski.

W epoce avignońskiej kolejni Biskupi Rzymu wydają pompatyczne dokumenty opisujące ich wszechwładzę nad Kościołem, cesarzem i królami ${ }^{14}$. Wtórują im 2 wielcy kanoniści: Włoch Augustyn z Ankony i Portugalczyk Alvaro Pelayo, których wizja światowej wszechwładzy papieskiej robi wrażenie na współczesnym czytelniku, do złudzenia przypominając mu nowożytną koncepcję absolutnej suwerenności, tyle, że o charakterze uniwersalnym ${ }^{15}$. W ich wizji Biskup Rzymu jest nie tylko panem świata doczesnego, lecz nawet Czyśćca, z którego może wyciągać dusze zmarłych, które nie trafiły jeszcze do Nieba (dopiero Niebo znajduje się poza władzą pontyfikalną) ${ }^{16}$. Zestawienie deklaracji papieży avignońskich i ich kanonistów z rzeczywistą niemocą polityczną Kościoła pokazuje jak bardzo teokratyczna teoria, odziedziczona po Grzegorzu VII i Innocentych III i IV oraz rzeczywistość empiryczna mogą rozejść się i wzajemnie do sobie nie przystawać17.

Gallikanizacja Kościoła avignońskiego spowodowała (słuszne) protesty w całej Europie, zakończone Wielką Schizmą Zachodnią (1378-1417), gdy obrano równocześnie

Times. Toronto 1980, s. 61n.; J.N. Figgis: Political Thought from Gerson to Grotius: 1414-1625. Kitchener 1999, s. 45n.; A. Boureau: La religion de l'Etat. La construction de la République étatique dans le discours théologique de l'Occident médiéval (1250-1350). Paris 2006, s. 248-49; J. Baszkiewicz: Myśl polityczna wieków średnich. Poznań 1998, s. 32-34.

${ }^{14}$ Zob. np. Benedykt XII: Super quibusdam [1349]. [w:] H. Denzinger (red.): Enchiridion Symbolorum. Monachii 1908, § 1050-65.

${ }^{15}$ Szerzej o obydwu kanonistach zob. N. Iung: Alvaro Pelayo - évêque et pénitencier de Jean XXII. Un Franciscain, théologien de pouvoir pontifical au XIVe siècle. Paris 1931; J. Morais Barbosa: O 'De Statu et planctu ecclesiae'. Estudio critico. Lisboa 1982; A. Wielomski: Teokracja papieska..., s. 577-614.

${ }^{16}$ Augustyn z Ankony: Summa de potestate ecclesiastica. Romae 1584, XVIII, 1-2; XX, 4; XXIX, 4; XXXII.

${ }^{17}$ J. Rivière: Le Problème de l'Eglise et de l'Etat au temps de Philippe Le Bel. Louvain-Paris 1926, s. 376; U. Mariani: Chiesa e Stato nei theologi agostiniani del secolo XIV. Roma 1957, s. 13. 
2 papieży (Urban VI i Klemens VII). Sytuację pogorszył jeszcze, zwołany jako naprawczy, Sobór w Pizie (1409), gdy zdeponowano następców zmarłych wcześniej 2 antagonistów i wybrano w ich miejsce Aleksandra V. Gdy jednak zdeponowani tejże depozycji nie uznali, to chrześcijaństwo miało już 3 suwerennych kapłanów. Fakt współwystępowania kilku papieży doprowadził do załamania się papalistycznej eklezjologii, czyli do upadku koncepcji, że Biskup Rzymu jest suwerenem w Kościele. W czasie Schizmy l. 1378-1417 upada idea Kościoła katolickiego jako europejskiego uniwersalnego super-państwa, opartego na prawie kanonicznym, z papieżem jako suwerenem, któremu podlegają królowie docześni.

Wspomniani wcześniej kanoniści Augustyn z Ankony i Alvaro Pelayo wyrażali jeszcze żywe eklezjalne przekonanie, że jakkolwiek en realité avignońskie papiestwo jest cieniem papalistycznego Kościoła Innocentego III, to formalnie papież panuje nad całym światem chrześcijańskim, a sam Kościół jest zbudowany niczym nowoczesne i scentralizowane państwo, wyprzedzając tym samym ideę statalizmu charakterystyczną dla epoki Renesansu. Przedłużająca się Wielka Schizma Zachodnia stopniowo zaczyna ten pogląd rugować. Zdezorientowani biskupi i wierni autentycznie nie wiedzą, kto jest eklezjalnym suwerenem. Nie ma suwerennego państwa uniwersalnego bez uniwersalnego suwerena. Stąd pojawienie się idei koncyliaryzmu, czyli supremacji soboru, który rozstrzygnie, kto jest prawowitym papieżem, ewentualnie zdeponuje wszystkich i obierze nowego. Gdy suwerenność papieża zachwiała się, należy odwołać się do rozstrzygnięcia ludu Bożego: owce same muszą zdecydować, kto jest ich pasterzem.

W późnośredniowiecznym koncyliaryzmie początkowo chodziło tylko o to, aby sobór powszechny orzekł, który z papieży jest prawowity. Miała mu zostać powierzona pełnia tradycyjnej suwerennej władzy nad światem ${ }^{18}$. Gdy okazało się to niemożliwe, to stopniowo zaczęła rodzić się doktryna o trwałej wyższości soboru nad papieżem i zastąpienia suwerenności pontyfikalnej przez koncyliarną ${ }^{19}$. Wyrazem zwycięstwa nowej tendencji był dekret Haec sancta (1415) Soboru w Konstancji, gdzie czytamy:

(Sobór) jest prawowicie zgromadzony w Duchu Świętym (...) i posiada władzę bezpośrednio od Chrystusa. Każdy, niezależnie od pozycji czy godności, z papieska włącznie, zobowiazany jest do postuszeństwa względem niego $w$ sprawach dotyczacych wiary i przezwy-

\footnotetext{
${ }^{18}$ A. Black: Monarchy and Community. Political Ideas in the Later Conciliar Controversy, 1430-1450. Cambridge 1970, s. 90-93.

${ }^{19}$ Ibidem, s. 7-52; O. de la Brosse: Le Pape et le concile. La comparaison de leurs pouvoirs à la veille de la Réforme. Paris 1965, s. 81-106; E. Voegelin: The Later Middle Ages. [w:] Idem: The Collected Works. T. XXI. Columbia 1998, s. 245-66; G. Alberigo: The Conciliar Church. [w:] T.M. Izbicki, C.M. Bellito (red.): The Church, the Councils and the Reform. The Legacy of the Fifteenth Century. Pittsboro 2008, s. 271-90.
} 


\section{$6 / 2017$}

ciężenia obecnej schizmy, jak również ogólnej reformy Kościoła Bożego w głowie i członkach. Ponadto (sobór) oznajmia, że każdy, niezależnie od zajmowanej pozycji, stanowiska czy godności, z papieska włącznie, jeśli uparcie będzie odmawiał posłuszeństwa zaradzeniom, orzeczeniom, postanowieniom lub nakazom tego świętego synodu i każdego następnego prawowicie zgromadzonego soboru we wskazanych sprawach lub z nimi zwiazanych, zarzadzonych obecnie lub w przyszłości (...) poddany zostanie stosownej pokucie i należycie ukarany ${ }^{20}$.

Gdybyśmy te słowa mieli porównać do jakiejś znanej nam deklaracji politycznej, to - jako politologowi - jako pierwsze przychodzą nam do głowy traktaty Jeana-Jacquesa Rousseau i Emmanuela Sieyèsa na temat pierwotnej suwerenności ludu, który ewentualnie ustanawiając nad sobą monarchę, pozostawia sobie pierwotną suwerenność, mając prawo zmienić zarówno osobę monarchy, jak i ustrój na republikański ${ }^{21}$. Dekret Haec sancta to eklezjalny odpowiednik Rewolucji z 1789 roku, tyle, że $w$ Kościele katolickim i prawie 400 lat wcześniej niż stało się to we Francji. Koncyliaryzm przerwał wielusetletni $a$ tradycję gregorianizmu, postrzegającej Kościół w formie uniwersalnej absolutnej i scentralizowanej monarchii ${ }^{22}$.

Gdy w 1517 roku Martin Luter ogłaszał swoje tezy przeciwko Kościołowi rzymskiemu, to - wbrew temu jako to przedstawiała przez stulecia protestancka historiografia - nie walczył z żadnym wszechmocnym i wielogłowym smokiem. Kościół instytucjonalnie był mocno osłabiony, jego władza centralna była cieniem w stosunku do tego, czym była w epoce gregoriańskiej. Sam protestantyzm także wzmocnił trend ku autonomizacji państwa terytorialnego wobec resztek po władzach uniwersalnych: papiestwa i cesarstwa, a to dlatego, że książęta, którzy przyjęli protestantyzm, automatycznie przestawali podlegać Kościołowi i cesarzowi, który dochował wierności wierze rzymsko-katolickiej. W ten sposób Luter - nie mając tego zresztą wcale na celu - stał się ideologiem niepodległej nikomu władzy książąt niemieckich, czyli suwerenności państwowej ${ }^{23}$. Terytorialna konfesja protestancka staje się pra-wzorem dla nowożytnych oficjalnych ideologii publicznych, ściśle oddzielając własnych poddanych-wiernych od obcych-innowierców, czyli od nielojalnych

\footnotetext{
${ }^{20}$ Haec sancta, 2-3. [w:] A. Baron, H.Pietras (red.): Dokumenty soborów powszechnych. T. III. Kraków 2005, s. $48-49$.

${ }^{21}$ J.J. Rousseau: Umowa społeczna. Poznań 1920 [1762]; E. Sieyès: Qu'est-ce que le Thiers-Etat? B.m.w. 1789.

${ }^{22}$ K. Schatz: Prymat papieski od początków do współczesności. Kraków 2004, s. 155-73.

${ }^{23}$ C.J.H. Hayes: Essays on Nationalism. New York 1933, s. 37-41; K. Brandi: Deutche Geschichte im Zeitlter der Reformation und Gegenreformation. Leipzig 1941, s. 45-62; Q. Skinner: The Foundations of Modern Political Thought. T. II. New York 1998, s. 54-58, 106-08; H.-U. Wehler: Nationalismus. Geschichte, Formen, Folgen. München 2001, s. 18-19.
} 
poddanych i od zagranicy ${ }^{24}$. Na terenie Rzeszy prawnie zasadę tę usankcjonował Traktat Westfalski $(1648)^{25}$.

Narodziny suwerennego państwa, cofnąć możemy do ostatnich wieków Średniowiecza, datując je na początek XIV wieku, gdy powstaje narodowa monarchia francuska. W przypadku Sycylii rządzonej przez Fryderyka II procesy te widzimy już kilkadziesiąt lat wcześniej i w jeszcze gwałtowniejszym wydaniu ${ }^{26}$. Generalnie jednak, aż do 1517 roku były to procesy powolne, często o charakterze punktowym na mapie Europy. Etatyzacja nie obejmowała w ogóle Niemiec, Anglii, Hiszpanii, Skandynawii i środkowej Europy. Dopiero Reformacja i wybuch ogólnoeuropejskiej konfesyjnej wojny domowej spowodowały wytryśnięcie scentralizowanego państwa narodowego nie tylko jako faktycznie podstawowego, ale formalnie jako jedynego podmiotu w stosunkach międzynarodowych. Zjawisko to dotyczyło zarówno państw protestanckich, jak i katolickich.

\section{Niespójność Kontrreformacji wobec instytucji państwa}

Gdy mobilizację polityczną przeciwko konfesyjnym wrogom przeprowadzały katolickie i protestanckie państwa narodowe, także Kościół katolicki, pod wodzą Rzymu, dołączył do tych zmagań. Fobia i nienawiść Martina Lutra i innych reformatorów do papiestwa spowodowała nagły wzrost jego autorytetu w oczach katolików, gdyż Rzym - do niedawna symbol renesansowego zepsucia - stał się dla nich symbolem religijnej ortodoksji. Czym częściej prawowierni katolicy słyszeli protestanckie legendy, że Biskup Rzymu jest Antychrystem ${ }^{27}$, tym chętniej gromadzili się pod jego sztandarami, aby dać odpór

\footnotetext{
${ }^{24}$ E. Voegelin: Die Politischen Religionen. München 2007, s. 43-48; W. Reinhard: Reformation, Counter-Reformation and the Early Modern State: A Reassessment. [w:] D.M. Luebke (red.): The Counter-Reformation. Malden 2005, s. 114n.

${ }^{25}$ I. Popiuk-Rysińska: Suwerenność w rozwoju stosunków międzynarodowych. Warszawa 1993, s. 48; O. Dann: Nation und Nationalismus in Deutschland 1770-1990. München 1996, s. 43-44; J. Bartelson: A Genealogy of Sovereignty, op.cit., s. 138; H. Schulze: Staat und Nation in der europäischen Geschichte. München 1999, s. 59-61, $143-44$.

${ }^{26}$ M. Garcia-Pelayo: Frederico II de Suábia e o nascimento do estado moderno. Minas Gerais 1961; A. Marongiù: Ein,Modellstaat' im italienischer Mittelalter. Das normannisch-staufische Reich in Sizilien. [w:] G. Wolf (red.): Stupor Mundi. Zur Geschichte Friedrichs II. von Hohenstaufen. Darmstadt 1982, s. 325-44; E. Maschke: Die Wirtschaftspolitik Kaiser Friedrichs II im Könichreich Sizilien. [w:] Ibidem, s. 349-94.

${ }^{27}$ Teza o papieżu jako Antychryście była b. popularna pośród teologów protestanckich, jak i pośród sfanatyzowanych religijnie mas w Rzeszy zob. np. V. Chaffour-Kestner: Etudes sur les réformateurs du XVIe siècle. T. I. Paris 1853, s. 97-111, 127-40; H. Münkler: Mity Niemców. Warszawa 2013, s. 123-78. Na temat tego mitu w Anglii zob. P. Lake: The significance of the Elizabethan identification of the Pope as Antichrist, "Journal of Ecclesiastical History", 1980, nr 31, s. 161-78; A. Milton: Catholic and Reformed. The Roman and Protestant Churches in English Protestant Thought, 1600-1640. Cambridge 2002, s. 93-127, 187-208; J. Basista: Propaganda religijna w przededniu i pierwszych latach angielskiej wojny domowej. Kraków 2007, s. 91-110.
} 
Reformacji. O ile w XV wieku króluje koncyliaryzm, to na Soborze w Trydencie (15451563) duch jest już odmienny i właściwie tylko biskupi francuscy, nominowani na swoje stanowiska przez króla na podstawie konkordatu bolońskiego (1516), stoją na pozycjach koncyliarystycznych i antypapieskich ${ }^{28}$. Sobór potwierdził prymat papieski, czyli tradycję przerwaną przez koncyliaryzm, ale nie zdefiniował tego pojęcia. Także w kwestii pontyfikalnej nieomylności ojcowie soborowi nie wypracowali klarownego stanowiska. W sumie był to znaczący krok w kierunku odbudowy monarchii pontyfikalnej, nie będąc jednak całkowitą restauracją gregoriańskiej pontyfikalnej plenitudo potestatis ${ }^{29}$.

Na Soborze w Trydencie większość miała opcja propapieska, złożona z ojców hiszpańskich i włoskich. Nie była to wszakże większość jednolita. Hiszpanie uznawali pontyfikalną nieomylność w kwestiach wiary, ale mieli kłopoty z akceptacją bezwarunkowego papieskiego prymatu jurysdykcyjnego nad Kościołem, a szczególnie nad państwem ${ }^{30}$. Wynikało to z faktycznego podporządkowania hiszpańskiego duchowieństwa iberyjskiej monarchii, na wzór gallikański (Patronato Real), gdzie królowie zwołują lokalne synody, wpływają na wybór biskupów i sankcjonują papieskie dokumenty przed ich ogłoszeniem na terenie królestwa ${ }^{31}$. Kontrreformacja hiszpańska i francuska charakteryzują się swoistym cezaropapizmem. We Francji, gdzie tenże cezaropapizm jest doktryną stanu, antyprotestantyzm królów wynika z przesłanek politycznych, a mianowicie stanowi pokłosie walki z hugenotami, którzy tworzą zbrojną neofeudalną i prawie jawnie republikańską partię polityczną. Katolicyzm francuskich królów łączy się z racją stanu państwa, będąc opcją polityczną za scentralizowaną i absolutną monarchią ${ }^{32}$. Teologiczno-polityczną figurę gallikańskiej i etatystycznej Kontrreformacji personifikuje bp Jacques Bossuet ${ }^{33}$. Kontr-

${ }^{28}$ V. Martin: Le Gallicanisme et la Réforme catholique. Essai historique sur l'introduction en France des décrets du Concile de Trente (1563-1615). Paris 1919, s. 166-200; H. Weber: L'accettazione in Francia del Concilio di Trento. [w:] P. Prodi, H. Jednin (red.): Il Concilio di Trento come crocevia della politica europea. Bologna 1979, s. 85-108. Biskupi ci realizowali bezpośrednie polecenia królewskie (Louis XIV: Instructions et lettres des Rois très-chretiens et de leurs ambassadeurs et autres actes concernant le concile de Trente. Paris 1654, s. 555-56).

${ }^{29}$ J. Pegon: Episcopat et hierarchie du Concile de Trente, „Nouvelle Revue Théologique”, 1960, nr 92, s. 580-88; G. Alberigo: Lo sviluppo della dottrina sui poteri nella Chiesa universale. Momenti essenziali tra il XVI e il XIX secolo. Roma 1964, s. 11-101; idem: Ecclesiologia del Concilio di Trento, „Rivista di Storia della Chiesa in Italia“, 1964, nr 18, s. 227-42; K. Ganzer: Gallikanische und römische Primatauffassung in Wiederstreit. Zudem ekklesiologischen Auseinandersetzungen auf dem Konzil von Trient, „Historisches Jahrbuch“, 1989, nr 109, s. 109-63.

${ }^{30}$ A.W. Ward: The Counter Reformation. London 1889, s. 86.

31 A.M. Ruoco Varela: Estado e Iglesia en la España del siglo XVI. Madrid 2001, s. 135n (do końca książki). W wielkim skrócie problem omawia R. Bireley: The Refashioning of Catholicism, 1450-1700. Washington 1999, s. 73-75.

${ }^{32}$ E. Thuau: Raison d'Etat et pensée politique à l'époque de Richelieu. Paris 2000, s. 183-87, 242-48; A. Jouanna: Le prince absolu. Apogée et déclin de l'imaginaire monarchique. Paris 2014, s. 20-27.

${ }^{33}$ F. Nourisson: La politique de Bossuet. Paris 1867, s. 139-40; A.-G. Martimort: Le gallicanisme de Bossuet. Paris 
reformacja wynikła z racji stanu stoi na stanowisku - którego nie przyjmuje i nie uznaje Rzym - że władza monarsza pochodzi bezpośrednio od Boga, bez pośrednictwa Kościoła ${ }^{34}$.

Biskupi włoscy w Italii nie posiadali nad sobą żadnego patronatu władzy doczesnej i byli ściśle powiązani z Rzymem, widząc w nim ośrodek jedności dogmatycznej, dyscyplinarnej, a często także politycznej, traktując Kościół niczym państwo ${ }^{35}$. Różnica ta powoduje fundamentalną niezgodę pomiędzy Hiszpanami i Włochami - czyli 2 narodami, które stały się fundamentami Kontrreformacji - co do politycznej roli i znaczenia papiestwa, a tym samym zdefiniowania podmiotowości w stosunkach międzynarodowych. Dla monarchii hiszpańskiej, aspirującej do panowania światowego, katolicyzm jest konfesją publiczną, którą posługują się monarchowie, tworzący teologiczno-polityczny konglomerat idei i interesów. Racja stanu Hiszpanii łączy się ze sprawą katolicką, gdyż Hiszpania przedstawia się jako wyrazicielka katolicyzmu politycznego i próbuje uzyskać monopol na reprezentację kwestii katolickiej i kontrreformacyjnej - oto tzw. prawdziwa racja stanu, różniąca się od makiawelizmu podporządkowaniem polityki sprawie Kościoła ${ }^{36}$.

Znaczące różnice polityczne pomiędzy państwami narodowymi powodują, że katolicy i hierarchowie poszczególnych narodowych kościołów katolickich inaczej definiują cele Kontrreformacji. Zgoda panuje jedynie w kwestiach stricte teologicznych. Odmienne poglądy uwidaczniają się w eklezjologii i w relacjach między państwem a Kościołem. Włoscy kanoniści chętnie widzieliby papieża w roli nieomylnego zarządcy Kościoła i politycznego suwerena świata katolickiego; francuscy przyznają mu tylko prymat honorowy i nie uznają jego roli politycznej; hiszpańscy uznają pontyfikalną nieomylność w kwestiach wiary, ale odmawiają papieżowi absolutnej jurysdykcji w kwestiach wewnątrzkościelnych. Wskutek tego polityka francuska XVI i XVII wieku ignoruje Biskupa Rzymu jako podmiot w stosunkach międzynarodowych i minimalizuje jego znaczenie eklezjalne, specjalnie nie

1953, s. 317-29; A. Wielomski: Kościół w cieniu gilotyny. Katolicyzm francuski wobec Rewolucji (1789-1815). Warszawa 2009, s. 59-78.

${ }^{34}$ Holistyczny wykład doktryny daje J. Bossuet: Défence de l'église gallicane [Defensio Declarationis celeberrimae, quam de potestate ecclesiastica sanxit Clerus Gallicanus]. Paris 1845 [1730], s. 55-82. Podobne poglądy znajdujemy u kard. A. de Richelieu (Oeuvres. Paris 1933, s. 154) i u francuskich legistów, np. G. Budé (De l'institution du Prince. Paris 1547, s. 30, 41-42, 155) i C. Le Bret (De la souveraineté..., s. 7, 179).

${ }^{35}$ P. Prodi: La sovranità temporale dei Papi e il Concilio di Trento. [w:] Ibidem, H. Jednin (red.): Il Concilio di Trento come crocevia della politica europea. Bologna 1979, s. 65-84; idem: Il sovrano pontefice. Un corpo e due anime: la monarchia papale nella prima età moderna. Bologna 1982; R. de Mattei: Il pensiero politico italiano nell'età della Controriforma. T. I. Napoli 1982, s. 211-20; t. II, s. 147-64.

36 J.A. Fernandez-Santamaria: Razon de Estado y politica en el pensamiento español del Barroco (1595-1640). Madrid 1986, s. 9-43; J. Peña Echeverría: Estudio preliminar. [w:] Idem (red.): La razón de Estado en España. Siglos XVI-XVII (Antología de textos), Madrid 1988, s. XXIV-XXXVIII 
rozważając nawet tej kwestii teoretycznie. Tymczasem teologowie i kanoniści hiszpańscy bardzo mocno podkreślają papieski prymat i nieomylność w Kościele ${ }^{37}$, równocześnie eliminując suwerennego pontifexa ze stosunków międzynarodowych na rzecz suwerennego państwa jako jedynego podmiotu politycznego ${ }^{38}$. Tradycję tę otwiera już ojciec Szkoły z Salamanki Francisco Vitoria ${ }^{39}$, a prawdziwą apoteozę państwa narodowego w stosunkach międzynarodowych daje największy z neoscholastyków, a mianowicie Francisco Suarez ${ }^{40}$. Podobne poglądy głosili najznamienitsi hiszpańscy prawnicy epoki Kontrreformacji: Diego de Covarrubis i Fernando Vazquez de Menchaca ${ }^{41}$.

Jedynym krajem w kontrreformacyjnej Europie gdzie, stworzona w czasie reformy gregoriańskiej, wizja tradycyjnej pontyfikalnej monarchii uniwersalnej - duchownej i politycznej - pozostaje w mocy są Włochy. Dzieje się tak dlatego, że nad Półwyspem nie ciąży władza jednego i silnego suwerena. Rozdrobniona Italia jest pod silnym wpływem pontyfikalnego monarchy pobliskiego Rzymu. Stąd popularna jest tutaj idea pontyfikalnego bezpośredniego panowania nad światem politycznym ${ }^{42}$.

\section{Nauka o państwie Roberta Bellarmina}

\section{Litera, Tradycja i rozum naturalny}

Poglądy Roberta Bellarmina na władzę pontyfikalną można podzielić na 2 sfery: władzę papieża w Kościele katolickim (prymat jurysdykcyjny, kwestia nieomylności dogmatycznej) i wobec świata doczesnego, czyli wobec państw. Jezuita ten był jednym z najbardziej znanych i elokwentnych obrońców papieskiego pełnego prymatu jurysdykcyjnego i jego nieomylności w kwestiach dogmatycznych. Jednak starannie rozdzielał

\footnotetext{
${ }^{37}$ U. Horst: Papst - Konzil - Unfehlbarkeit. Die Ekklesiologie der Summenkommentare von Cajetan bis Billuart. Mainz 1978, s. 26-161, 187-251; C. Hermann: Papisme et national-catholicisme espagnols, mi-XVe/mi-XVII siècle, "Bulletin de la Société d'Histoire Moderne et Contemporaine", 2000, nr 3-4, s. 17-34.

${ }^{38}$ J.-A. Maravall: La philosophie politique espagnole au XVIIe siècle dans ses rapports avec l'ésprit de la contreréforme. Paris 1955, s. 165-86; F. De los Rios: Religion y Estado en la España del siglo XVI. Mexico 1957, s. 94-130; B. Hamilton: Political Thought in Sixteenth-Century Spain. A Study of political Ideas of Vitoria, de Soto, Suárez, and Molina. Oxford 1963, s. 98-109; J.A. Fernandez-Santamaria: The State, War and Peace. Spanish Political Thought in the Renaissance, 1516-1559. Cambridge 1997, s. 11-57.

${ }^{39}$ F. Vitoria: Leçons sur les Indiens et sur le droit de guerre [De Indis]. Genève 1966 [1532], s. 46-58

${ }^{40}$ J.M. Gallegos Rocafull: La Doctrína Política del P. Francisco Suárez. Mexico 1948, s. 209-34; H. Rommen: La teoria del Estado y de la communidad internacional en Francisco Suarez. Buenos Aires 1951, s. 447-506; 209-34; J. Soder: Francisco Suárez und das Völkerrecht. Grundgedanken zu Staat, Recht und internationale Beziehungen. Frankfurt am Main 1973, s. 220-309.

${ }^{41}$ L. Pereña Vicente: Diego de Covarrubis y Leyra. Maestro de derecho internacional. Madrid 1957, s. 70-72, 133-48; F. Carpintero Benitez: Del derecho natural medieval al derecho natural moderno: Fernando Vazquez de Menchaca. Salamanca 1977, s. 244-50.

${ }^{42}$ R. de Mattei: Il pensiero politico..., t. I, s. 212-33.
} 


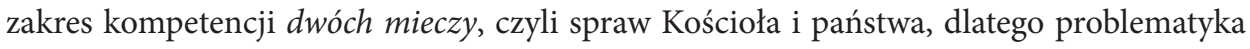
wszechwładzy papieskiej wewnątrz Kościoła nie miała bezpośredniego wpływu na jego poglądy dotyczące stosunków międzynarodowych i nie będziemy jej tutaj omawiać. Czytelników zainteresowanych kwestią papalistyczną odsyłamy do lektury rozdziału 4 pracy O papieskiej monarchii eklezjalnej (De Romani Pontificis ecclesiastica monarchia, 1586) ${ }^{43}$ lub do literatury przedmiotu ${ }^{44}$.

W interesującej nas kwestii stosunków międzynarodowych, a szczególnie kompetencji papieskich, poglądy Roberta Bellarmina wzbudzały zawsze żywe kontrowersje, zarówno w czasie jego życia, jak i w literaturze przedmiotu. Bellarmin był autorem polemicznym, afirmującym tradycyjne stanowisko katolickie w starciu z tezami protestantów lub odstępców od Magisterium kościelnego. Tak też należy pojmować jego polemikę wokół władzy pontyfikalnej w samym Kościele, której celem było intelektualne unicestwienie eklezjologii reformowanej ${ }^{45}$, negującej instytucję papieża z racji nie występowania tej instytucji w Literze biblijnej ${ }^{46}$. W polemice z protestantami włoski jezuita negował pojmowanie Litery jako jedynego źródła wiary, wskazując na rolę Tradycji katolickiej, czyli na 2 równorzędne źródła wiary: Literę i Tradycję ${ }^{47}$.

Tradycja stanowi źródło Bellarminowej nauki o władzy pontyfikalnej i doczesnej, acz nie chodzi tu o bezrefleksyjne przyjmowanie poglądów kościelnych, byle tylko doszło do zadawnienia ich źródła, co pozwoliłoby uznać je za objawione czy też przypisać ich genezę apostołom lub pierwszym chrześcijanom, pamiętającym Chrystusa. Kontrreformacja włoska i hiszpańska przybiera formę neoscholastyki (neotomizmu), podkreślając rolę rozumu naturalnego, logiki i filozofii arystotelesowskiej ${ }^{48}$. Każde istotne twierdzenie znaleźć przeto musi 3 potwierdzające je argumenty: z Litery, z Tradycji (pisanej i apostolskiej)

\footnotetext{
${ }^{43}$ R. Bellarmin: De Romani Pontificis ecclesiastica monarchia [1586]. [w:] Idem: Disputationes. De controversiis christianae fidei, adversus huius temporis Haereticos. Parisiis 1608, IV De potestate spirituale, t. I, kol. 791-874.

${ }^{44}$ U. Horst: Papst - Konzil, op.cit., s. 169-86. Nieco informacji na ten temat podają też prace: F.X. Arnold: Die Staatslehre des Kardinals Bellarmin. Ein Beitrag zur Rechts- und Staatsphilosophie des konfessionellen Zeitalters. München 1934, s. 326-30; A. Richardt: Saint Robert Bellarmin. Le défenseur de la foi, 1542-1621. Paris 2004, s. 193-96; F. Motta: Bellarmino. Una teologia politica della Controriforma. Brescia 2005, s. 366-71.

${ }^{45}$ A. Schubert: Bellarmin und die lutherische Ekklesiologie des Konfessionellen Zeitalters, „Evangelische Theologie“, 2015, nr 75, z. 2, s. 135-51.

${ }^{46} \mathrm{~Np}$. F. Melanchton: De la puissance et authorité de la sainte eglise chretienne et comment elle peut etre cogneuë par la Parolle de Dieu [tyt. oryg.?]. B.m.w. 1543, s. 2AB-20A; M. Luter: Büchlein von der babylonischen Gefängnis der Kirche. [w:] Idem: Die reformatischen Schriften. T. II. Darmstadt 1847, s. 37-162; J. Calvin: Institution de la Religion chrétienne. Paris 1888, ks. IV, rozdz. VI-VIII.

${ }^{47}$ R. Bellarmin: De Verbo Dei [1586]. [w:] Idem: Disputationes, op.cit., t. I (kol. 127-208). Zwięzłe omówienie problemu daje J. Beumer: Die Frage nach Schrift und Tradition bei Robert Bellarmin, „Schol“, 1959, nr 34, s. 1-21.

${ }^{48}$ Zob. klasyczny wykład M. Cano: Locis theologicis. Salamanca 1562, IX, 4; IX, 8; X, 5-6.
} 
i z rozumu. Po te ostatnie Bellarmin sięga szczególnie wtedy, gdy czuje, że argumenty stricte teologiczne nie zapewniają mu zwycięstwa w polemice. Przeistacza się wtenczas z teologa w filozofa.

Nauka św. Tomasza silnie oddziałuje na filozofię polityczną Roberta Bellarmina, acz jego tomizm polityczny - jak zresztą wszystkich tomistów aż po początek XX wieku skażony jest błędnym przypisaniem Akwinacie autorstwa istotnego traktatu politycznego O królowaniu, gdy w rzeczywistości św. Tomasz napisał tylko początek tej pracy i prawie cała wyszła spod ręki Ptolemeusza z Lukki, który nadał jej teokratyczny kierunek ${ }^{49}$. Mimo tej niewiedzy włoski jezuita zachowuje podstawową dla oryginalnego św. Tomasza zasadę autonomii porządku natury i porządku duchowego (nadprzyrodzonego), z ostatecznym przekonaniem, że to, co duchowe udoskonala i uzupełnia to, co doczesne („łaska nie burzy porządku natury, lecz go udoskonala" ${ }^{\prime 0}$ ). 160 lat temu H.-R. Feugueray bardzo trafnie skomentował tę myśl Akwinaty:

Wszędzie gdzie łaska łączy się z natura, to nie po to, aby niszczyć, ale aby się dołaczyć do niej, wznieść ja dzięki swojej dominacji. To kapitalne rozróżnienie znajdujemy także $w$ nauce o polityce. Jakkolwiek prymat ma racjonalna polityka i filozofia, to gdzieś ponad niq jest polityka teologiczna, której celem nie jest jednak wywrócenie tej pierwszej, lecz modyfikacja jej celów i dodanie jej nowego charakteru. Porządek naturalny społeczeństw ludzkich jest uzupetniany $i$ wznoszony dzięki porzadkowi nadnaturalnem $u^{51}$.

$\mathrm{Z}$ tej tomistycznej tezy Bellarmin wyprowadza pogląd o istnieniu autonomicznego porządku doczesnego i religijnego, państwa i Kościoła, władzy politycznej i władzy eklezjalnej, które w stanie idealnym ściśle ze sobą współpracują w tzw. kwestiach mieszanych. Chodzi o ochronę religii, osób i dóbr Kościoła przez państwo w zamian za legitymizację władzy monarszej poprzez jej sakralizację. Nie bez znaczenia jest także gregoriańska tradycja kanonistyczna, szczególnie dekretały Innocentego III, często przez Bellarmina cytowane, a które podkreślają autonomię sfery doczesnej od kościelnej.

\section{Naturalny charakter państwa}

Zgodnie z omówioną powyżej tradycją, także i Robert Bellarmin wywodzi źródło władzy politycznej z prawa natury i arystotelesowsko-tomistycznie pojętej naturalnej

\footnotetext{
${ }^{49}$ Tomasz z Akwinu, Ptolemeusz z Lukki: O królowaniu. Królowi Cypru. Kraków 2006. Odkrył to dopiero w 1920 r. M. Grabmann (Die echten Schriften des hl. Thomas von Aquin. München 1920, s. 216n.).

${ }^{50}$ Oryg.: gratia non tollit naturam sed perficit, Tomasz z Akwinu: Summa Theologiae, na stronie internetowej corpusthomisiticum.org, II, II, k. 10, a. 10.

${ }^{51}$ H.-R. Feugueray: Essai sur les doctrines politiques de Saint Thomas d'Aquin. Paris 1857, s. 31.
} 
koncepcji powstania państwa. W traktacie O laikacie (De laicis sive secularibus, 1586) znajdujemy znakomity wywód w którym widać klasyczną filozofię polityczną i duch czystego Arystotelesa. Dlatego decydujemy się na przytoczenie obszernych fragmentów tegoż wywodu:

Władza polityczna jest tak naturalna i niezbędna ludzkości, że nie można jej usunąc nie niszcząc samej natury. Z natury czlowiek jest istotą społeczną. Gdy zwierzęta $z$ natury umieja zachować samowystarczalność, to człowiek potrzebuje tak wielu rzeczy, że nie jest zdolny do życia pojedynczego. Zwierzęta rodza się $w$ futrach i uzbrojone, maja instynkt wyczuwajacy wszystko, co jest dla nich dobre. Wiedza $z$ natury i bez żadnej nauki jak zbudować gniazdo, znaleźć pożywienie, znaleźć lekarstwo w razie choroby. Człowiek rodzi się bez ubrania, bez domu, bez jedzenia. Brakuje mu wszystkiego, nawet jeśli ma ręce i rozum za pomoca których może wszystko wyprodukować, to każda rzecz wymaga długiego czasu, aby ja zrobić, dlatego jest rzecza niemożliwa, aby człowiek był samowystarczalny we wszystkim. $W$ dodatku rodzi się bez umiejętności i wszystkich ich musi się dopiero wyuczyć, często od nauczycieli, a nie dzięki doświadczeniu. Dlatego musimy żyć wspólnie, aby jeden pomagat drugiemu $u^{52}$.

Zaraz potem Bellarmin dodaje:

Jeśli nawet założylibyśmy, że człowiek jest samowystarczalny w życiu, to nadal nie jest samowystarczalny $w$ ochronie samego siebie przed atakiem zwierzat lub złodziei. Dla ochrony ludzie musza zebrać się i bronić wspólnymi siłami. Gdybyśmy nawet przypuścili, że człowiek jest samowystarczalny przeciwko zagrożeniom, to nadal pozostaje bez rzemiosła, wiedzy, sprawiedliwości i innych cnót, które nie sa nam wrodzone, a dzięki którym możemy używać naszych woli i rozumu. Nauka i rzemiosło rozwijaja się od setek lat i sa dziełem wielu ludzi. Nie można tego opanować bez nauczyciela. Sprawiedliwość także nie istnieje poza społeczeństwem, gdyż jest cnota relacyjna względem innych ludzi. A w końcu po co człowiekowi bylyby dary mowy i stuchu, czyli posługiwania się słowami, gdyby miał być sam?53.

No i wreszcie zacytujmy uwieńczenie tego naturalistycznego wywodu w postaci koncepcji politycznej:

Skoro natura ludzka domaga się życia społecznego, to domaga się także istnienia rządu i władcy, gdyż jest rzecza niemożliwa, aby ogół był dłużej zebrany w jedno, jeśli ktoś nie będzie go zbierał i dbał o dobro wspólne. Bez siły jednoczącej, poszczególne grupy wejda

\footnotetext{
${ }^{52}$ R. Bellarmin: De laicis sive secularibus [1589]. [w:] Idem: Disputationes, op.cit., t. II, V (kol. 510B-D).

${ }^{53}$ Ibidem, V (kol. 510D-E).
} 
ze sobq $w$ konflikty. (...) Społeczeństwo to ogót uporządkowany, gdyż ogót skonfliktowany i rozrzucony nie może być tak nazwany. A czymże jest porzadek jak tylko podporzadkowaniem niższych swoim przełożonym? Jeśli społeczeństwo ma istnieć, to musi mieć władców ${ }^{54}$.

W słowach tych włoski jezuita zdecydowanie odrzuca charakterystyczny dla wczesnego Średniowiecza tzw. augustynizm polityczny (termin wprowadzony w XX wieku przez H.-X. Arquillière’a) głoszący, że władza polityczna ma swoje źródło w woli Kościoła $\mathrm{i}$ istnieje wyłącznie na mocy jego postanowienia lub przywileju ${ }^{55}$. Bellarmin przywołuje zresztą argument empiryczny: władza Nimroda, faraonów, królów babilońskich i izraelskich, Cezara i Augusta istniała całe stulecia przed narodzinami Jezusa Chrystusa i założeniem przezeń Kościoła. Władza polityczna jest przeto starsza niż chrześcijaństwo, a więc nie może pochodzić z udzielenia kościelnego. Opisy historyczne i biblijne dowodzą, że zwykle jej źródłem była przemoc, uzurpacja i zagarnięcie ${ }^{56}$, czyli środki nie tyle naturalne, co wulgarnie naturalistyczne.

Zgodnie ze starą tradycją scholastyczną Bellarmin uważa, że ludzie z natury rodzą się równi i wolni, a panowanie i poddaństwo są skutkami grzechu pierworodnego ${ }^{57}$. Bóg uczynił człowieka wolnym i racjonalnym, czyli istotą, która miała dominować wyłącznie nad bezrozumnymi zwierzętami ${ }^{58}$. Jednakże, z powodu grzechu i perwersji ludzkiej natury, ludzie dominują i panują jedni nad drugimi. Pismo Święte akceptuje władzę doczesną taką jaką stworzyliśmy, uznając każdą jej formę za pochodzącą od Boga, a Nowy Testament pozwala chrześcijanom ją sprawować i stoi na stanowisku, że monarchowie są zastępcami Boga na ziemi ${ }^{59}$.

Zgodnie z zasadami prawa rzymskiego i kanonicznego Bellarmin starannie i konsekwentnie oddziela urząd od osoby ${ }^{60}$. Uznaje, że władza (instytucja) pochodzi z natury i posiada sankcję Boską. Sankcję tę ma jednak sam urząd - z tej racji, że pochodzi z wymogów natury, których twórcą jest Bóg ${ }^{61}$ - a nie konkretna osoba ją sprawująca:

\footnotetext{
${ }^{54}$ Ibidem, V (kol. 511AB).

${ }^{55}$ Pojęcie ukuł i rozpropagował H.-X. Arquillière: L'Augustinisme politique. Essai sur la formation des théories politiques du Moyen-Age. Paris 1972.

${ }^{56}$ R. Bellarmin: De laicis sive secularibus, op.cit., I (kol. 506A).

${ }^{57}$ Ibidem, I (kol 506B); VII (kol. 514DE). O scholastycznych źródłach tego poglądu zob. R.W. Carlyle, A.J. Carlyle: History of mediaeval political Theory. T. II. Edinburgh 1903-50, s. 117-35.

${ }^{58}$ R. Bellarmin: De laicis sive secularibus, op.cit., I (kol. 506C).

${ }^{59}$ R. Bellarmin: De laicis sive secularibus, op.cit., II (kol. 507-08).

${ }^{60}$ F.X. Arnold: Die Staatslehre des Kardinals..., s. 108-13, 173-74, 181.

${ }^{61}$ R. Bellarmin: De laicis sive secularibus, op.cit., VI (kol. 510E-511A).
} 
Władza (potestas) pochodzi z prawa Bożego. Ale prawo Boże nie dało tejże władzy żadnemu konkretnemu człowiekowi. Dało je wszystkim (...). Ale ta władza, z tegoż samego prawa natury, przekazywana jest przez ogół jednemu lub nielicznym, bowiem wspólnota nie umie sprawować sama władzy nad sobą. (...) poszczególne formy rządów pochodza z prawa narodów (iure gentium ${ }^{62}$ ), a nie z prawa natury. Ustanowienie sobie królów, konsulów lub innych instytucji zależy od zgody ludzkiej. I jeśli jest ku temu prawowity powód, to ogół może zmienić monarchię w arystokrację lub $w$ demokrację i odwrotnie, tak jak to bywało $w$ Rzymie ${ }^{63}$.

Czyli sama idea konieczności władzy wynika z natury ludzkiej, tę zaś stworzył Bóg. Pośrednio, tylko pośrednio Bóg stworzył państwo i władzę, a bezpośrednio dokonali tego sami ludzie. Dlatego instytucje te to - jak pisze o. Arnold - „rezultat wspólnego dzieła łaski Bożej i ludzkiej aktywności”" ${ }^{4}$. Fałszem jest anglikańska teoria Boskich praw królów i idea, że władcom udzielono specjalnej łaski i mają wyższy status ontologiczny ${ }^{65}$. Konsekwentnie, równie prawowite są monarchia, arystokracja, demokracja (co do której jezuita wyraża jednak duży sceptycyzm) i rządy mieszane ${ }^{66}$. Osobiście jezuita preferuje monarchię ograniczonąa ${ }^{67}$.

Zauważmy, że Bellarminowa teoria zakłada, że pierwotnie suwerenność należy do ludu, który przekazuje ją suwerenowi. Jezuita pisze o elekcji pierwszego władcy. Teza ta pochodzi od św. Tomasza ${ }^{68}$ i cieszyła się dużą popularnością pośród teologów i myślicieli politycznych Kontrreformacji, szczególnie zaś jezuitów ${ }^{69}$. Czy Bellarmin był więc zwolennikiem suwerenności ludu i prekursorem idei Jeana-Jacquesa Rousseau? Nie, odpowiada analizujący problem o. Arnold, ponieważ nie istnieją u niego podstawowe kategorie roussoistyczne:

1) Brak jest wizji umowy społecznej w wyniku której jednostki-atomy zakładają państwo. Władzę suwerenowi przekazuje nie zebrany na jakiejś mitycznej leśnej polanie

\footnotetext{
${ }^{62}$ R. Bellarmin zawsze używa terminu „iure gentium” nie w znaczeniu prawa narodów, czyli prawa międzynarodowego, lecz na oznaczenie prawa ludzkiego, a więc dotyczącego np. ustroju, prawa karnego lub cywilnego.

${ }^{63}$ R. Bellarmin: De laicis sive secularibus, op.cit., VI (kol. 512A-C).

${ }^{64}$ F.X. Arnold: Die Staatslehre des Kardinals..., s. 189.

${ }^{65}$ Ibidem, s. 84-91.

${ }^{66}$ R. Bellarmin: De Romani Pontificis, op.cit, I, 1 (kol. 505B).

${ }^{67}$ Ibidem, I, 1-3 (kol. 505-513).

${ }^{68}$ P. Bourdin: La théologie politique de saint Thomas. [w:] Ch. Zarka (red.): Aspects de la pensée médiévale dans la philosophie politique moderne. Paris 1999, s. 25-43.

${ }^{69}$ Zob. np. A. Couartou: La souveraineté populaire chez Francisco Suarez. Bordeaux 1974; L. Cedroni: La comunità perfecta. Il pensiero politico di Francisco Suárez. Roma 1996, s. 81-104; I. Gómez Robledo: El origen del poder político según Francisco Suárez. Mexico 1998, s. 59-194.
} 
tłum jednostek, lecz społeczeństwo zorganizowane w rodziny i wspólnoty terytorialne, mające charakter hierarchiczny. W wyborze suwerena udział biorą tylko elity. Kontrakt dotyczy formy ustrojowej i osoby (osób) rządzących, gdzie stroną społeczną nie jest roussoistyczny suwerenny lud ${ }^{70}$. Używając kategorii socjologii Ferdinanda Tönnisa, Franz X. Arnold pisze, że stroną umowy nie jest liberalne społeczeństwo (die Gesellschaft), lecz wspólnota (die Gemeinschaft) ${ }^{71}$.

2) Pierwotna suwerenność społeczeństwa kończy się w momencie ustanowienia ustroju i władcy. Ani lud w całości, ani jego elity nie mogą jednostronnie cofnąć raz udzielonej delegacji ${ }^{72}$ po akcie koronacji, która ma charakter religijny. Po sakrze monarszej władza już nie pochodzi od ludzi, lecz od Boga i tylko Bóg (w Jego zastępstwie papież) może zmyć święty charakter olejów wtenczas użytych, w razie zaistnienia tyranii. Biskup Rzymu jest interpretatorem kontraktu, ponieważ tylko on ma moc starcia jego religijnego charakteru: aktu pomazania i przysięgi poddanych w obliczu Boga o posłuszeństwie wobec suwerena. Dokąd papież nie obłoży suwerena ekskomuniką i nie zdeponuje go, dotąd nie istnieje legalne aktywne prawo do oporu ${ }^{73}$.

Zasada pochodzenia władzy od ludu i nienaturalności tyranii, pisze Robert Bellarmin, dotyczy wszystkich wspólnot mających pochodzenie ludzkie, a nie nadprzyrodzone. Nie dotyczy więc jedynie Kościoła, gdzie Chrystus osobiście przekazał pełnię władzy w ręce św. Piotra i jego następców, co czyni ustrój Kościoła ex definitione monarchicznym i sprawiedliwym ${ }^{74}$. Jest to pogląd bardzo typowy dla nauki jezuickiej, głoszącej ideę, że władza polityczna pochodzi od Boga pośrednio, a pontyfikalna bezpośrednio ${ }^{75}$.

Niestety, w rządach doczesnych tyranie są częste. Bellarmin zastanawia się czy jest to kara Boża za grzech (stanowisko św. Augustyna) czy wynik sprzeniewierzenia się prawu natury? Ostatecznie dochodzi do wniosku, że jest to ciężkie wykroczenie przeciwko naturze i zasadom rzymskiego prawa publicznego, skoro suweren zaczyna traktować swoich

\footnotetext{
${ }^{70}$ F.X. Arnold: Die Staatslehre des Kardinals..., s. 133-37, 155-56, 196-202.

${ }^{71}$ Ibidem, s. 93.

${ }^{72}$ Ibidem, s. 229-38.

73 Ibidem, s. 238.

${ }^{74}$ R. Bellarmin: De Romani Pontificis, op.cit, I, 1 (kol. 505A); I, 2 (kol. 511CD); I, 10-15 (kol. 539-61); 1, 21-23 (kol. 575-81); I, 25 (kol. 585-89); II, 15-16 (kol.640-43); idem: De laicis sive secularibus, op.cit., VI (kol. 512CD). Nawiasem mówiąc w krążącym w Rzymie memorandum do Klemensa VIII, wydanym drukiem dopiero w 1913r., R. Bellarmin nie odmalowuje współczesnego mu Kościoła w tak różowych barwach, widząc w nim wiele nadużyć i nieprawidłowości (De officio primario Summi Pontificis, w: Auctarium Bellarminianum. Paris 1913, s. 513-18).

${ }^{75}$ H. Höpfl: Jesuit Political Thought. The Society of Jesus and the State, c. 1540-1630. New York 2004, s. 225, 239-53.
} 
poddanych (politica subiectione) niczym niewolników (despotica subiectione) ${ }^{76}$. Poddany słucha praw i płaci podatki, ale z natury jest właścicielem samego siebie, gdy cała własność i osoba niewolnika należą do pana, który może go zabić lub ograbić dzięki dominacji fizycznej. Król rządzi dla dobra wspólnego, gdy tyran dla dobra własnego ${ }^{77}$. Istotą królowania jest sprawiedliwość, czyli realizacja dobra. To zaś osiągane jest dzięki posłuszeństwu rozumowi. Ludzki rozum nie potrzebuje łaski, aby pojąć, co jest dobre i sprawiedliwe ${ }^{78}$. Dlatego król-poganin może rządzić sprawiedliwie, czyli zgodnie z prawami natury, z których jednym z najważniejszych jest przestrzeganie prawa i wystrzeganie się arbitralności. W prawie Bożym wspólnota, nawet pogańska, zawsze może partycypować przestrzegając praw natury i stanowiąc sobie prawa ludzkie, które z nich wynikają ${ }^{79}$.

Wspólnota doczesna ma charakter doskonały (samowystarczalny) w sprawach politycznych i materialnych. Ma monopol na rozstrzyganie kwestii stricte doczesnych. Władza suwerena kończy się tam, gdzie zaczyna się religia i kwestia zbawienia. Bellarmin odrzuca historyczne i współczesne mu protestanckie teorie cezaropapistyczne, jak i nadmierną sakralizację władzy monarszej, czyniącej z królów niby-kapłanów (teoria tzw. Boskiej władzy królów) ${ }^{80}$. Władza doczesna jest zobowiązana chronić religię chrześcijańską przed bluźniercami, heretykami i poganami, a czynić to winna z dobrze pojętego własnego interesu, gdyż „wolność religijna jest niszcząca dla porządku doczesnego i pokoju publicznego", ponieważ „dysydencja religijna prowadzi do dysydencji duchowej i odmiennej woli, a każde królestwo wewnętrznie podzielone upada"81. Jak widzimy, nawet obrona ortodoksji i zwalczanie "prawa do błędu” (libertas errandi) ${ }^{82}$ podane są w narracji racjonalistycznej i naturalnej, a nie konfesyjnej. Kościół nie ma także prawa do egzekucji heretyków. Uznając danego człowieka za heretyka ma prawo domagać się od władzy doczesnej, aby go ujęła, osądziła, skazała i ewentualnie wykonała karę główną ${ }^{83}$.

\footnotetext{
${ }^{76}$ R. Bellarmin: De laicis sive secularibus, op.cit., V (kol. 514E).

${ }^{77}$ Ibidem, V (kol. 514D-515A).

${ }^{78}$ Problem istoty i rozpoznania prawa natury u R. Bellarmina znakomicie charakteryzuje niemiecki jezuita-tomista o. F.X. Arnold: Die Staatslehre des Kardinals..., s. 38-76.

${ }^{79}$ R. Bellarmin: De laicis sive secularibus, op.cit., XI (kol. 520C-E).

${ }^{80}$ Ibidem, XVII (kol. 538B-E). Na temat doktryny Boskiej władzy królów zob. klasyczną pracę J.N. Figgis: The Divine Right of Kinges. New York 1965.

${ }^{81}$ R. Bellarmin: De laicis sive secularibus, op.cit., XVIII (kol. 541AB).

${ }^{82}$ Ibidem, XVIII (kol. 541B).

${ }^{83}$ R. Bellarmin: De Romani Pontificis, op.cit, I, 5 (kol. 516AB); idem: De laicis sive secularibus, op.cit., XXI (kol. 548-51);.
} 
Jak widzimy, w całym tym wywodzie Robert Bellarmin przestrzega autonomii władzy doczesnej w stosunku do eklezjalnej, posiłkując się tutaj tradycyjną teorię o odrębności $d$ wóch mieczy $y^{84}$. Traktuje suwerenne państwo jako prawowity podmiot stosunków międzynarodowych, któremu wolno jest prowadzić wojny, o ile tylko są to wojny sprawiedliwe $^{85}$ (w rozumieniu charakterystycznym dla teologii mediewalnej i neoscholastycznej ${ }^{86}$ ).

\section{Kompetencje papieskie wobec państwa}

\section{Władza bezpośrednia (potestas directa)}

Uznając państwo za prawowity podmiot stosunków międzynarodowych Robert Bellarmin zaprzecza augustynizmowi politycznemu, jak i mediewalnej teorii bezpośredniej władzy pontyfikalnej nad światem, która pod koniec Średniowiecza - pomimo upadkowi papiestwa w wyniku Niewoli Avignońskiej, Wielkiej Schizmy Zachodniej i koncyliaryzmu - zyskiwała coraz większą popularność pośród kanonistów. Gdy biskupi chcieli rozwiązać problemy wewnątrzkościelne powierzając władzę soborowi (czyli samym sobie), to kanoniści widzieli lekarstwo na upadek autorytetu Kościoła w radykalnym wzmocnieniu papieskiego autorytetu ${ }^{87}$. W epoce Bellarmina doktrynę bezpośredniego skupienia dwóch mieczy w rękach papieskich głosili w Italii Tomasso Bozio, Tomasso Campanella, Antonio Santarelli ${ }^{88}$, a także krótko panujący hierokratyczny papież Sykstus V. Pogląd ten podzielał także pochodzący z Anglii Albert Pighius ${ }^{89}$.

Z powodu zatargu z Sykstusem V (o którym jeszcze będzie mowa) Bellarmin nie odważył się na bezpośrednią polemikę z, faworyzowanym przezeń, Tomasso Bozio, zadowalając się refutacją poglądów znanych już nam, a dawno nie żyjących Alvaro Pelayo

\footnotetext{
${ }^{84}$ R. Bellarmin: De laicis sive secularibus, op.cit., XVIII (kol. 540D), XXII (kol. 555CD).

${ }^{85}$ Ibidem, XV (kol. 533-535).

${ }^{86}$ Rola R. Bellarmina w rozwoju teorii wojny sprawiedliwej w epoce Kontrreformacji jest minimalna - zob. R.H.W. Regout: La doctrine de la guerre juste d'après les théologiens et canonistes catholiques. Aalen 1974, s. 242-43. Wyjaśnia tę lukę F.X. Arnold, dowodzący, że sprawy międzynarodowe zostały opisane w manuskryptach $\mathrm{z}$ lat młodzieńczych (komentarz do Summy teologicznej Akwinaty), które nie zostały wydane drukiem. Badacz ten opisuje je w swojej pracy Die Staatslehre des Kardinals..., s. 271-95. Szerzej na temat wkładu neoscholastyków do prawa międzynarodowego i idei wojny sprawiedliwej zob. klasyczne prace: R.H.W. Regout: op.cit., s. 149-274; A. Vanderpol: La doctrine scholastique de droit de guerre. Paris 1925, s. 15-159.

${ }^{87}$ G. Glez: Pouvoir du pape dans l'ordre temporel. [w:] A. Vacant, E. Mangenot (red.): Dictionnaire de théologie catholique. T. XII/2. Paris 1935, s. 2670-2772.

${ }^{88}$ F. Bozio: De temporali ecclesiae monarchia. Coloniae 1602; A. Santarelli: Tractaus de haeresi, schismati, apostasia et de potestate romani Pontificis. Roma 1625, XXX-XXXI; T. Campanella: Monarchia Messiae. Torino 1960 [1633], s. 23-28 (książka trafiła zresztą na Index z powodu zawartej w niej wizji millenarystycznej papieża-anioła). Znana nam literatura na ten temat jest nikła: S. Mastellone: Tomasso Bozio, teorico dell'ordine ecclesiastico, „Il Pensiero Politico“, 1980, nr 13, s. 186-94; R. de Mattei: Il pensiero politico..., t. I, s. 214-20).

${ }^{89}$ A. Pighius: Hierarchiae ecclesiasticae assertio ad Paulum III libri sex. Coloniae 1551, V.
} 
i Augustynem z Ankony ${ }^{90}$. W niepublikowanych manuskryptach zaciekle polemizuje także z wielkim teoretykiem hierokracji kanonistą Hostencjuszem ${ }^{91}$. W polemikach tych włoski jezuita dowodzi, że „papież i papiestwo z prawa Bożego nie posiadają żadnej władzy doczesnej i w żadnym razie nie mogą panować nad władcami doczesnymi, jak i pozbawić ich władzy w ich królestwach i księstwach"92. Papież nie jest panem doczesnym ani świata, ani chrześcijaństwa. Nie może nawet obalić władców-pogan: „Papież jest monarchą duchowym nad całym globem ziemskim, ale nigdy nie sprawował władzy nad całym globem ziemskim"93.

Robert Bellarmin dowodzi, że Bóg zakazał komukolwiek łączenia w jednym ręku obydwu mieczy, tak monarchom (cezaropapizm), jak i duchownym (papocezaryzm). Jeśli papież w praktyce wykonuje władzę doczesną w Państwie Kościelnym, to uzyskał ją drogą "donacji”, a nie „uzurpacji”, czyli podboju ${ }^{94}$. Podobnie istnieć mogą księstwa lub miasta należące do poszczególnych biskupstw i tworzące niezależne ośrodki polityczne (w rozproszkowanym politycznie cesarstwie), o ile "pochodzą z donacji władców lub zostały objęte w posiadanie uczciwie" ${ }^{\prime 95}$.

Uzasadnienie tego stanowiska ma charakter nowotestamentowy i racjonalny. Prawo Boże nie dało Biskupowi Rzymu władzy bezpośredniej nad żadnym państwem, ponieważ jest on „wikariuszem Chrystusa” na ziemi, a Tenże wzgardził władzą doczesną (kuszenie na pustyni), nauczając, że moje królestwo nie jest $z$ tego świata, z czego „wynika ewidentnie, że Chrystus, także jako człowiek śmiertelny, nie pożądał królestwa doczesnego, a więc papież, czyli Wikariusz Chrystusa, także nie powinien go mieć" ${ }^{\prime 96}$. Chrystus zawiódł mesjańskie oczekiwania ludu Izraela, gdyż nie chciał być doczesnym Rex Iudaeorum, a przecież nikt nie może przekazać spadkobiercy niczego, czego sam nie posiada, czyli nie przekazał władzy doczesnej swoim następ $\operatorname{com}^{97}$. Za brakiem pontyfikalnej władzy

\footnotetext{
${ }^{90}$ R. Bellarmin: De Romani Pontificis, op.cit, V, 1.

${ }^{91}$ F.X. Arnold: Die Staatslehre des Kardinals..., s. 335. Hostencjusz (Henryk z Suzy) był mistrzem prawa kanonicznego dla hierokraty Innocentego IV. Szerzej na temat tego kanonisty zob. A. Rivera-Damas: Pensamiento politico de Hostiensis. Estudio juridico-histórico sobre las relaciones entre el Sacerdocio y el Imperio en los escritos de Enrique de Susa. Zürich 1964; J.A. Watt: The Theory of papal Monarchy in the Thirteenth Century. The Contribution of the Canonists. New York 1965, s. 107-34.

92 R. Bellarmin: De Romani Pontificis, op.cit, V, 1 (kol. 875B).

93 Ibidem, V, 2 (kol. 876C).

94 Ibidem, V, 1 (kol. 875B). Chodzi o donację ziem zdobytych na Longobardach przez Pepina Krótkiego (753).

${ }^{95}$ Ibidem, V, 1 (kol. 876BC).

96 Ibidem, V, 4 (kol. 879D).

${ }^{97}$ B. Bourdin: La genèse théologico-politique de l'Etat moderne: la controverse de Jacques Ier d'Angleterre avec le cardinal Bellarmin. Paris 2004, s. 115.
} 
bezpośredniej przemawia także racja rozumowa: zadaniem Kościoła jest doprowadzenie jak największej liczby ludzi do zbawienia. Nie można tego osiągnąć panując politycznie nad monarchami. Z punktu widzenia soteriologicznego jest to właściwie kwestia zbędna ${ }^{98}$.

Omawiana w tym podrozdziale księga V Bellarminowego traktatu O papieskiej monarchii eklezjalnej kończy się wnioskiem, że Biskupi Rzymu posiadają tylko władzę pośrednią nad światem, mogąc za zbrodnie i występki ekskomunikować i zdeponować króla-tyrana i zwolnić poddanych z przysięgi posłuszeństwa. Nie mają już jednak ani siły militarnej, ani innej mocy, aby te depozycje zmaterializować. Jest to w gestii samych poddanych, którzy jeśli chcą, mogą się zbuntować i prawomocnie obalić tyrana ${ }^{99}$.

\section{Pontyfikalna władzy pośrednia (potestas indirecta)}

Tezy o władzy pontyfikalnej Roberta Bellarmina, zawarte w pracy O papieskiej monarchii eklezjalnej (i w innych rozprawach ${ }^{100}$ ), zostały uznane za zbyt daleko idące przez część angielskich katolików, cierpiących srogie jarzmo w protestanckiej Anglii, szczególnie po nieudanej próbie zamachu na króla Jakuba VI/I, podjętej przez garść desperatów (1605). Gdy część z wyspiarskich katolików zachowywała posłuszeństwo Rzymowi tak w kwestiach wiary, jak i dyscypliny, to u innej części pojawiły się tendencje do podjęcia kolaboracji z protestanckim państwem, zachowując wiarę i ryt, lecz za cenę dyscyplinarnego nieposłuszeństwa wobec Rzymu. Polemika wiązała się z zagadnieniem praktycznym, a mianowicie z problemem posłuszeństwa wobec Elżbiety I po jej ekskomunice i depozycji przez Piusa V (1570) ${ }^{101}$, gdy katolicy nie odważyli się na bunt. Jednak zamach z 1605 roku przypomniał o problemie, a zamachowcy byli papalistami, związanymi z jezuitami.

Wyrazicielem doktryny kolaborantów był William Barclay, autor rozprawy $O$ władzy papieskiej i o tym jaka władzę posiadaja królowie i władcy docześni (De potestate papae, an et quantenus in reges et principes saeculares jus et imperium habeat, 1607). Jego rozprawa miała charakter polemiczny w stosunku do jezuickiej koncepcji pośredniej władzy papieża nad królami, w tym także w stosunku do księgi V O papieskiej monarchii eklezjalnej ${ }^{102}$. Na

\footnotetext{
${ }^{98}$ R. Bellarmin: De Romani Pontificis, op.cit, V, 4 (kol. 881E).

${ }^{99}$ Ibidem, V, 6-8 (kol. 887-97).

${ }^{100}$ Wyliczenie wszystkich dzieł i miejsc, gdzie R. Bellarmin porusza ten problem znaleźć można u J.C. Murray: St. Robert Bellarmin on the indirect Power, "Theological Studies", 1948, nr 9, s. 494-95.

${ }^{101}$ Pius V: Bulle 'Regnans in excelsis' [1570] . [w:] C. Mirbt: Quellen zur Geschichte des Papsttums und des römischen Katholizismus. Tübingen-Leipzig 1901, nr 338, s. 266-67.

${ }^{102}$ W. Barcley: Traité de la Puissance du pape sur les princes seculiers [De potestate papae, an et quantenus in reges et principes saeculares jus et imperium habeat]. Cologne 1687 [1607], s. 1-2, 8-10, 114-243, 268-70, 291306, 320-75, 380-93.
} 
modłę jawnie protestancką angielski katolik twierdzi, że władza papieska nie ma uzasadnienia w Literze ${ }^{103}$. Nie była znana Kościołowi przez pierwszych 7-10 wieków jego historii, dlatego pogląd o jej prawowitości może mieć co najwyżej status prywatnej „opinii” kanonistów i teologów ${ }^{104}$. Chrystus zakazał mieszania się apostołom w sprawy władzy doczesnej, a więc „duchowny nie powinien przypisywać sobie funkcji, aktów, godności i jakichkolwiek prerogatyw władców doczesnych”, w związku z czym „książęta i dostojnicy kościelni są w sprawach doczesnych poddanymi władców politycznych"105.

Konsekwentnie, William Barclay dowodzi, że Biskup Rzymu posiada moc duchową nad królami, ale wyłącznie jako osobami prywatnymi. Dlatego apostołowie i Ojcowie zalecali zawsze pełne posłuszeństwo, a pierwsi chrześcijanie modlili się za prześladujących ich pogańskich cesarzy ${ }^{106}$. Z tego powodu angielski katolik ogłoszenie przez Piusa V depozycji Elżbiety I uznaje za „słowa absolutnie fałszywe i chimeryczne” i stanowiące „świętokradczą uzurpację" ${ }^{107}$. Doktryna prawa papieży do depozycji monarchów miałaby być osobistą rewolucyjną ideą Grzegorza VII, który wymyślił sobie, że ma prawo ekskomunikować i zdeponować cesarza ${ }^{108}$. Po kilku stuleciach podobnych praktyk, uzurpacja ta zaowocowała politycznie uprawnionym powszechnym buntem władców przeciwko tejże uzurpacji w postaci Reformacji, której angielskim wyrazem był Akt Supremacji $(1534)^{109}$. Zdaniem Barclay’a, katolik może uznawać prymat papieski wyłącznie w kwestiach wiary i rytu, gdyż „w kwestiach doczesnych władcy za swojego sędziego uznają tylko Boga”110. Oznacza to niemożność wyrokowania ani przez papieży, ani przez poddanych, czy dany monarcha jest czy nie jest tyranem, skoro „Bóg wprost nakazał honorować władców, być posłusznym ich rozkazom, nie rozróżniając dobrych władców od złych”"111. Jak zwracaliśmy uwagę przy innej okazji, anglikańska teologia polityczna tzw. Boskiego prawa królów praktycznie kasuje klasyczne rozróżnienie na władcę prawowitego i tyrana, zakazując osądzać suwerena za jego uczynki ${ }^{112}$. Barclay uznaje to twierdzenie.

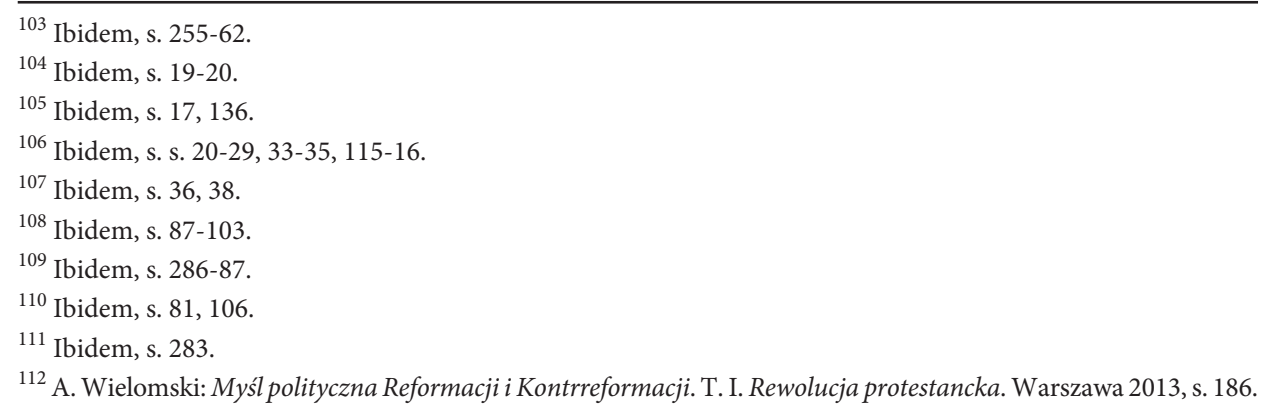


Charakteryzujemy szerzej dzieło Williama Barclay’a, ponieważ zmusiło Bellarmina do napisania rozprawy polemicznej w postaci Traktatu o władzy papieskiej w kwestiach doczesnych przeciwko Williamowi Barclay'owi (Tractatus de potestate Summi Pontificis in repubus temporalibus adversus Gulielmum Barclaium, 1610), gdzie wyłożył ponownie swoją koncepcję władzy pośredniej, łatwo odpierając zarzuty swojego polemisty, nad którym zresztą zdecydowanie górował erudycyjnie.

Główne zarzuty Bellarmina wobec teorii Barclay’a są następujące:

1) Negacja Tradycji. W swoich tezach Barclay jest zupełnie osamotniony, jest całkowicie „sam przeciwko zwartej kolumnie wszystkich katolickich pisarzy”, gdyż jego „opinia jest niespotykana i przeciwstawna wszystkim katolickim autorom, tak teologom, jak i wykładowcom prawa kanonicznego i świeckiego"113. Angielski katolik jawi się nam jako religijny nowator, stojący w opozycji do „wielu papieży i patriarchów, arcybiskupów, biskupów”, a także „kilku soborów”114. Cała Tradycja katolicka jednym głosem przyznaje papieżowi mniejsze lub większe uprawnienia kontrolne nad państwami doczesnymi i spory dotyczą jedynie jej zakresu' ${ }^{115}$. Ekskomunikując i deponując Henryka IV, Grzegorz VII zmaterializował prawa przynależące papiestwu od zawsze, z woli Chrystusa ${ }^{116}$. We wstępie do swojej rozprawy jezuita zebrał cytaty z dzieł 70 teologów i kanonistów z Italii, Francji, Hiszpanii, Portugalii, Niemiec, Anglii i Szkocji oraz liczne cytaty z postanowień soborów i dekretów papieskich, dowodzące, że Biskup Rzymu posiada dobrze ugruntowaną pośrednią władzę nad państwami chrześcijańskimi ${ }^{117}$. Barclay występując w tej kwestii sam jeden przeciw jest heretykiem wobec powszechnego stanowiska kościelnego, a odrzucenie Tradycji katolickiej stanowi przecież istotę protestantyzmu (sola Scriptura).

2) Niezgoda z Literą. W swojej pracy Barclay chętnie powołuje się na Literę, aby wykazać, że Jezus Chrystus nie posiadał i nie chciał posiadać jakiejkolwiek władzy politycznej, a więc nic mógł przekazać św. Piotrowi i jego następcom władzy, której nie miał.

${ }^{113}$ R. Bellarmin: Tractatus de potestate Summi Pontificis in repubus temporalibus adversus Gulielmum Barclaium. Monachij 1712 [1610], s. 9-10.

${ }^{114}$ Ibidem, s. 10.

${ }^{115}$ Ibidem, s. 50, 230. Zdaniem R. Bellarmiena, najpoważniejszy argument W. Barclay’a brzmi, że papieże nigdy nie ekskomunikowali pogańskich cesarzy Rzymu. Jezuita przyznaje, że jest to prawda, ale zarzut ten można odeprzeć stwierdzeniem, że nie czynili tego dlatego, że chrześcijanie stanowili zdecydowaną mniejszość w cesarstwie i bunt był skazany na klęskę. Żaden z Ojców Kościoła nie negował takiego uprawnienia, czekając, aż chrześcijanie zdobędą większość. Wczesna Tradycja chrześcijańska uznawała takie uprawnienie papieskie de iure, ale z powodu słabości politycznej duchowni nie wykonywali go de facto (ibidem, s. 54, 58-60, 90-92, 95-100, 214-17).

${ }^{116}$ Ibidem, s. 73-74.

${ }^{117}$ Ibidem, s. 11-39. 
Bellarmin odpowiada, że lektura Biblii rzeczywiście nie przyznaje następcom św. Piotra władzy bezpośredniej. Jednak Litera uprawomocnia pontyfikalne roszczenia do władzy pośredniej, gdyż w Starym Testamencie są opisane przypadki skutecznej depozycji monarchów przez kapłanów, a w Nowym Testamencie mamy kilka fragmentów powierzających św. Piotrowi pieczę nad chrześcijaństwem, które mogą zostać zinterpretowane w duchu papalistycznym (Mt. 16, 18-19; J. 21, 15; 21, 17, etc) ${ }^{118}$. Taką też wykładnię tych fragmentów znajdujemy w Tradycji.

3) Negacja historii. Zawartą w Literze (tylko w formie implicite) tezę o istnieniu pontyfikalnej władzy pośredniej, którą Tradycja przekształciła w explicite, można potwierdzić świadectwami historycznymi, gdy Biskupi Rzymu rzeczywiście dokonali ekskomuniki i depozycji władców przy wsparciu świętych, teologów, kanonistów i biskupów na soborze lub w rozproszeniu (Grzegorz II zdeponował cesarza Leona Izauryjczyka, Zachariasz króla Franków Childeryka, Grzegorz IV króla Franków Ludwika Pobożnego, Grzegorz VII cesarza Henryka IV, bp Mediolanu św. Ambroży cesarza Teodozjusza, Leon III dokonał translacji imperium, etc. $)^{119}$. Przy okazji widzimy jak ważna jest rola historii dla katolickiego teologa epoki Renesansu: stanowi doświadczalne potwierdzenie dla teorii eklezjalnej zawartej w Tradycji katolickiej ${ }^{120}$.

Wreszcie w Traktacie o władzy papieskiej w kwestiach doczesnych przeciwko Williamowi Barclay’owi znajdujemy uściślone zasady prawomocnego buntu wobec tyrana i związane z tym kompetencje pontyfikalne:

1) Definicja tyrana. Określenie, kto jest tyranem, a kto popełnił liczne występki, ale jeszcze nie zasługuje na takie zakwalifikowanie, ma charakter subiektywny, ponieważ definicja tyrana pióra Arystotelesa - którą posługiwano się od czasu recepcji pism Filozofa w Średniowieczu - ma charakter moralny: tyran to ten, kto rządzi dla dobra własnego, a nie dla dobra wspólnego ${ }^{121}$. Obiektywizacja pojęcia tyranii zainteresowała prawników późno mediewalnych, poczynając od Bartolo da Sassoferato w XIV wieku, który wyróżnił

\footnotetext{
${ }^{118}$ Ibidem, s. 51-52, 84-85, 148. R. Bellarmin nie ukrywa, że w przytaczanych przezeń fragmentach nie ma tej doktryny sformułowanej wprost i jej wyprowadzenie wymaga interpretacji alegorycznej (ibidem, s. 150). F. Motta zapewne słusznie uważa, że niejasność Litery, a w ślad za tym źródeł wiary, wymaga nieomylności papieskiej dla jej ostatecznej autorytatywnej wykładni (Bellarmino, op.cit., s. 367).

${ }^{119}$ R. Bellarmin: Tractatus de potestate..., s. 76-77, 110-29, 318-20, 324-36. J.C. Murray wylicza, że w pismach R. Bellarmina znajduje się 12 omówionych przypadków skutecznych ekskomunik i depozycji władców przez kapłanów (St. Robert Bellarmin..., s. 518-19).

${ }^{120}$ F. Motta: Bellarmino, op.cit., s. 367.

${ }^{121}$ Arystoteles: Polityka. Warszawa 2002, III, 5, 4-5; IV, 8, 3.
} 
2 rodzaje tyranów: uzurpatorów (ex defectu tituli) i despotów (ex parte exerciti) ${ }^{122}$, przeistaczając tym samym określenie moralne (często wręcz obelgę) w termin jurydyczny ${ }^{123}$.

W pismach Bellarmina uzurpacja prawie w ogóle nie jest rozważana jako znamię władzy tyranicznej. Uzurpator jest przestępcą i winien zostać obalony i potraktowany jak bandyta ${ }^{124}$. Co innego, jeśli umocni swoją władzę, zdobędzie jej uznanie u poddanych i przekaże ją potomkowi. Wtedy jest to już panowanie prawowite. Jezuita problem zbywa stwierdzeniem, że z punktu widzenia celów Kościoła nie jest istotna prawomocność dojścia do władzy, lecz jedynie sposób jej wykonywania ${ }^{125}$. Kościół jest zainteresowany tym, czy władza posiada lub nie posiada despotycznego charakteru.

Z kolei despotyzm rządów w praktyce zostaje, przez jezuitę, ograniczony do jednej jedynej kwestii istotnej dla epoki zmagań konfesyjnych: jeśli monarcha dokonuje apostazji z Kościoła katolickiego i zachęca lub zmusza do tego swoich poddanych, to jest tyranem ${ }^{126}$. Trudno nie odnieść wrażenia, że kierując się swoistą raison d'Eglise Robert Bellarmin jest w stanie wybaczyć monarchom klasyczne tyrańskie atrybuty: niemoralność w życiu prywatnym i ciemiężenie poddanych podatkami lub arbitralnymi rządami ${ }^{127}$. Zapewne dlatego nie występuje u niego klasyczna teokratyczna doktryna, że tyran to ten, kto publicznie grzeszy - Bellarmin nigdy nie posługuje się pojęciem ratione peccati Innocentego III, jako dowodem nieprawomocności panowania ${ }^{128}$. Ważne jest dlań tylko to, aby monarchowie czynnie zwalczali protestantyzm. Charakterystyczne, że nigdy nie pisze o dziejących się za jego życia wydarzeniach Nocy Św. Bartłomieja (1572), nie wypomina także gallikanizmu francuskim monarchom, mimo że w imieniu Sykstusa V jeździł do Francji z misjami dyplomatycznymi w obronie autonomii lokalnego Kościoła.

Redukcja problematyki tyranii do kwestii konfesyjnej, połączona z milczeniem na temat metod walki stosowanej z protestantami, zbliża Bellarmina do stanowiska zwanego

\footnotetext{
${ }^{122}$ D. Quaglioni: Politica e diritto nel Trecento Italiano. Il 'De Tyranno' di Bartolo da Sassoferrato (1314-1357). Città di Castello 1983, s. 43; J. Barthas: Formes de gouvernement ou modalités de la preuve? Eclaircissements sur le 'Traité du tyran' de Bartole da Sasseferato. [w:] Idem (red.): Della tirania: Machiavelli con Bartolo. Firenze 2007, s. 50.

${ }^{123}$ D. Quaglioni: Politica e diritto..., s. 31-32, 39; J. Barthas: Formes de gouvernement..., s. 47, 53-59.

${ }^{124}$ F.X. Arnold: Die Staatslehre des Kardinals..., s. 245.

${ }^{125}$ R. Bellarmin: Tractatus de potestate..., s. 316-17.

${ }^{126}$ Ibidem, s. 208, 220, 243. Podobnie byłoby w wypadku hipotetycznym wypadku, gdyby papież popadł w herezję i począł głosić nieortodoksyjną naukę. W takiej sytuacji przestaje być papieżem, po orzeczeniu zwołanego specjalnie w tym celu soboru (ibidem, s. 220-22).

${ }^{127}$ J.C. Murray: St. Robert Bellarmin..., s. 516-17.

${ }^{128}$ Ibidem, s. 498.
} 
mianem tzw. czarnego tacytyzmu (il tacitismo nero - tacytyzm duchownych), czyli akceptacji wszelkich środków, byle służyły stłumieniu Reformacji ${ }^{129}$.

2) Tyranobójstwo i prawo do oporu. W epoce konfliktów konfesyjnych, gdy wyznanie władcy zwykle nie pokrywało się z wyznaniem wszystkich jego poddanych, a w ramach odgórnej konfesjonalizacji królowie wymuszali na poddanych konwersję na własne, traktowane jako publiczne, karierę zrobiła stara kwestia tyranobójstwa. W dywagacjach teoretycznych na ten temat specjalizowali się szczególnie kalwini, a konkretnie angielscy i szkoccy purytanie ${ }^{130}$, ale idea ta dotarła także do katolików. Zasztyletowanie króla Francji Henryka III przez mnicha Jacquesa Clémenta (1589) i wspomniana wcześniej próba zabicia Jakuba VI/I (1605) są tego dostatecznym dowodem praktycznym, acz na gruncie teoretycznym katolicy ustępowali protestantom. Jedynym katolickim pisarzem głoszącym prawo do prywatnego zabójstwa tyrana był hiszpański jezuita Juan de Mariana ${ }^{131}$.

Jezuici zdecydowanie odcięli się od teorii Mariany ${ }^{132}$, a więc Bellarmin - który słuchał jego wykładów w Collegium Romanum - musiał być posłuszny stanowisku zakonu w tej kwestii, co przyszło mu o tyle łatwo, że jego erudycja kanonistyczna uprzywilejowywała myślenie w kategoriach prawa publicznego, a nie anarchicznych odruchów indywidualnych. W Traktacie o władzy papieskiej $w$ kwestiach doczesnych przeciwko Williamowi Barclay’owi włoski jezuita kilkakrotnie odcina się od prywatnego tyranobójstwa. Wszelka władza, nawet tyrańska i dokonująca konfesyjnej apostazji, dla poddanych pochodzi od Boga. Żadna osoba prywatna nie ma prawa decydować czy król jest czy nie jest tyranem,

${ }^{129}$ G. Toffanini: Machiavelli e il 'Tacitismo'. La 'Politica storica' al tempo della contrariforma. Napoli 1972, s. 12770; P. Badillo O’Farrell: Retorno al tacitismo y la Razón de Estado. [w:] Ibidem, M.A. Pastor Pérez (red.): Tácito y tacitismo en España. Barcelona 2013, s. 86-95.

${ }^{130}$ Element ten widać już w późnych reedycjach prac samego Kalwina w wersji francuskiej (Institution de la Religion..., IV, XX, 31-32), a szczególnie w angielskiej (Institutes of the christian religion. Peabody 2009 [1581], IV, XX, 30-31). Problem rozwijają późniejszy pisarze kalwińscy: G. Buchanan: Jure Regni apud Scotos, or a Dialogue Concerning the due Priviledge of Government In the Kingdom of Scotland [Jure Regni apud Scotos]. London 1689 [1579], V; VIII; J. Knox: The Appellation to the Nobility of and Estates [1558]. [w:] Idem: On Rebellion. Cambridge 2004, s. 98-99, 104; idem: Knox and Mary Queen of Scots [1561]. [w:] Ibidem, s. 178-79; J. Althusius: Politica Methodice digesta atque exemplis sacris \& profanis illustrata. Herbornae Nassoviorum 1614 [1610], XVIII; XXXVIII. W odróżnieniu do tych autorów, monarchomachowie francuscy są przeciwni samowoli jednostkowej w kwestii tyranobójstwa, oczekując zachęty do oporu w tradycyjnym pojęciu tego słowa ze strony krajowych ciał pośredniczących - zob. klasyczną pracę Junius Brutus (Ph. Duplessis-Mornay, H. Languet?): De la puissance legitime du prince sur le peuple, et du peuple sur le Prince [Vindiciae Contra Tyrannos sive, de principis in Populum, Populique in Principem, legitima postestate]. B.m.w. 1581, s. 81-83, 111-16, 218-19, 233, 236-37, 241-42.

131 J. de Mariana: Antologia. Madrid b.r.w., s. 95-101.

${ }^{132}$ Ch. Hansen Roses: Ensayo sobre el pensamiento politico del padre Juan de Mariana. Santiago 1959, s. 334-35;

D. Ferraro: Tradizione e ragione in Juan de Mariana. Milano 1989, s. 233-34. 
po czym - w przypadku odpowiedzi pozytywnej - zabić go ${ }^{133}$. Bellarmin uważa, że taka decyzja jednostki rodzi się poza prawem publicznym na którym zbudowane jest nowoczesne państwo.

Podobnie Robert Bellarmin stoi na stanowisku, że poddani nie mają prawa do samowolnego buntu wobec króla uznanego przez nich za tyrana - i dotyczy to nawet chrześcijan zamieszkałych w krajach pogańskich - ponieważ nie posiadają publicznej kompetencji, aby wydać prawomocny osąd w tej sprawie. Jest to nadal stanowisko jednostek, nawet jeśli bunt popiera większość lub ogół poddanych ${ }^{134}$. Jest to stanowisko zdecydowanie bardziej umiarkowane od niektórych pisarzy jezuickich (R. Persons w Anglii), którzy po odcięciu się od doktryny prywatnego tyranobójstwa Mariany, stali na stanowisku, że sumienie decyduje czy zaistniała sytuacja do stawienia tyrańskiej władzy czynnego oporu przez poddanych ${ }^{135}$.

Robert Bellarmin nie zgadza się z woluntaryzmem swoich współbraci zakonnych Juana de Mariany i Roberta Personsa. Legitymowalnej oceny występowania ewentualnej tyranii monarszej może dokonać tylko inny podmiot prawa publicznego. Nie jest nim inne państwo, będące równym podmiotem prawa publicznego. W tej sytuacji pozostaje jedynie autorytet Kościoła, w osobie suwerennego pontifexa, który uprawomocnienie swojego istnienia czerpie z wyższego, względem państwa doczesnego, porządku ontologicznego. Stojący ponad państwami Biskup Rzymu, zastępca Chrystusa na ziemi, jako jedyny może zawyrokować obiektywnie czy dany władca jest tyranem. Wynika to z bezdyskusyjnego papieskiego monopolu na udzielanie dyspens od przysięg i ślubów, w tym wypadku od przysięgi lojalności ${ }^{136}$ Gdy papież nakłada na tyrana - w interesującym Bellarmina przypadku: heretyka i apostatę od wiary katolickiej - ekskomunikę, to pozbawia jego władzę legitymizacji. Będący ustami Chrystusa rzymski pontifex tym samym ogłasza, że władza ekskomunikowanego przestała pochodzić od Boga, iż prawomocny król jeszcze sprzed chwili, właśnie stał się uzurpatorem, czyli osobą prywatną, która przywłaszczyła sobie prawo panowania w katolickim kraju. W tym momencie bunt i obalenie go stają się prawomocne. Suarez dopuszcza wtedy nawet prywatne tyranobójstwo ${ }^{137}$. Innymi słowy, ekskomunika nie jest tylko aktem religijnym, lecz prawnym, „to nie tylko - pisze Bellarmin - pozbawienie sakramentów i posługi kapłańskiej, ale także pozbawienie uprawnienia do funkcjonowania w roli

\footnotetext{
${ }^{133}$ R. Bellarmin: Tractatus de potestate..., s. 96-97, 331.

${ }^{134}$ Ibidem, s. 208-10.

${ }^{135}$ H. Höpfl: Jesuit Political..., s. 234-39.

${ }^{136}$ R. Bellarmin: Tractatus de potestate..., s. 218-19, 244-51.

${ }^{137}$ H. Höpfl: Jesuit Political..., s. 257.
} 
prawowitego członka systemu społecznego i prawnego"138. Ekskomunikowany jest zmarłym dla świata żywych.

3) Opis procedury depozycji tyrana. Bellarmin stoi na stanowisku, że działania pontyfikalne wobec tyrana nie mogą być podejmowane ad hoc i w sposób nieprzemyślany. Akty pontyfikalne przeciwko suwerenowi doczesnemu nie są opiniami doktora prywatnego, lecz urzędu (kanoniczne rozróżnienie sedens vs sedes ${ }^{139}$ ) i są obowiązujące tylko wtedy, gdy są ogłoszone ex cathedra (publicznie, uroczyście i z powołaniem się na autorytet urzę$\mathrm{du}$ ). Działania prawne papieża winny być także poprzedzone upomnieniem kandydata na tyrana, aby dać mu szansę zmienić swoją politykę (np. zaniechać planów rewolucji konfesyjnej lub w wyznaczonym terminem wrócić na łono Kościoła). Jeśli upomnienie nie przyniesie skutków, to Biskup Rzymu obkłada monarchę-apostatę ekskomuniką i tym samym deponuje go $\mathrm{z}$ tronu, zmieniając jego naturę ontologiczną z suwerena, którego władza pochodzi od Boga, w zwykłego człowieka okupującego tron królewski. W tym momencie poddani stają się ex-poddanymi i mają prawo obalić tyrana, ponieważ papież zwolnił ich z przysięgli lojalności wobec monarchy ${ }^{140}$.

Nie jest u Bellarmina do końca klarowne czy po papieskiej ekskomunice i depozycji poddani mają uprawnienie do przeprowadzenia leglitymowalnego buntu czy też jest to ich obowiązek? Raz jezuita pisze, że ekskomunikując i deponując tyrana rzymski pontifex kończy swoje dzieło i pozostawia dotychczasowym poddanym decyzję o podjęciu lub nie podjęciu działań: „po zwolnieniu z przysięgli lojalności (...) wykonanie należy do innych" ${ }^{\text {"141 }}$. Jednak w innym miejscu pisze, że prawomocny bunt jest ich obowiązkiem wobec Kościoła i nie podjęcie go może skutkować ekskomuniką poddanych lojalnych wobec króla lub interdyktem nałożonym na całe państwo ${ }^{142}$. Jeszcze gdzie indziej dowodzi, że papież może przymusić poddanych do buntu, ale nie musi tego czynić, zostawiając sprawę ich decyzji ${ }^{143}$. Prawdę mówiąc, to ostatnia wersja wydaje się nam najbardziej logiczna, gdyż dla samego Rzymu jest najbardziej wygodna.

Na sam koniec Robert Bellarmin podkreśla, że ekskomunika jest zawsze ważna, nawet jeśli podane w niej powody okazałaby się nieprawdziwe. Depozycja nie jest kwestią

\footnotetext{
${ }^{138}$ R. Bellarmin: Tractatus de potestate..., s. 280-81.

${ }^{139}$ W. Ullmann: Leo I and the theme of papal primacy, „Journal of Theological Studies”, 1960, nr 11, s. 25-51.

${ }^{140}$ R. Bellarmin: Tractatus de potestate..., passim.

${ }^{141}$ Ibidem, s. 97.

${ }^{142}$ Ibidem, s. 51-52.

${ }^{143}$ Ibidem, s. 104.
} 
ocenną, lecz należy ją traktować jako rozstrzygnięcie o charakterze prawno-publicznym wydane przez pontyfikalnego suwerena ${ }^{144}$. To analogia to zakazu buntu. Tak jak nie ma prawowitej rewolucji bez pontyfikalnej zezwolenia, tak nie ma i subiektywnej oceny ważności tegoż zezwolenia. Podmiot orzekający na mocy prawa publicznego nie może być oceniany subiektywnie przez podmioty prywatne. Jest także racja polityczna. Jest jedno jedyne miejsce, gdzie Bellarmin zgadza się z Barclay’em: w państwie nie może być dwuwładzy papieża i monarchy. Jean Bodin ma rację, że suwerenność jest niepodzielna i „to samo ciało nie może mieć dwóch głów” (ne sint in uno corpore duo capita) ${ }^{145}$. Suweren jest jeden $i$ jest nim rzymski pontifex.

\section{Wewnętrzne sprzeczności doktryny}

\section{Sprzeczności immanentne}

W teorii Bellarminowy podział władzy pontyfikalnej na bezpośrednią i pośrednią jest jasny i klarowny. Ale czy rzeczywiście papież ma tylko władzę pośrednią? Nowatorstwo Bellarmina w stosunku do tradycyjnej scholastyki, bazującej na Literze biblijnej, Tradycji i literaturze teologicznej oraz filozoficznej, polegało na dobrej znajomości historii. Liczba cytowanych przezeń kronikarzy i historyków jest doprawdy imponująca, wskazując na prowadzenie przezeń szeroko zakrojonych badań w dziedzinie historii Kościoła i styku polityki z religią. I właśnie analiza dziejów i współczesnych wydarzeń politycznych wskazała mu 2 przypadki (współczesny historyk mógłby ich wymienić więcej), gdy papieże dokonali bezpośredniej ingerencji w rządy doczesne:

1) Koronując Karola Wielkiego na cesarza (800) Leon III dokonał „przeniesienia cesarstwa" (translatio imperii) od Greków (Bizancjum) do Franków ${ }^{146}$. Uzasadnieniem tej decyzji był interes Kościoła, który potrzebował bliskiego geograficznie obrońcy doczesnego. Dodajmy, że cesarz to nie był to tylko ładny tytuł, gdyż monarcha nim obdarzony z mocy prawa stawał się zwierzchnikiem politycznym wszystkich królów i książąt katolickich.

2) W czasie wielkich odkryć geograficznych u progu Nowożytności papieże podzielili nowo odkrywane ziemie pomiędzy Hiszpanów i Portugalczyków. Nie chodzi tylko o słynny podział świata przez Aleksandra VI (1493), ale i o (zapomniane dziś) dokumen-

\footnotetext{
${ }^{144}$ Ibidem, s. 75, 187.

145 Ibidem.

${ }^{146} \mathrm{O}$ problemach politycznych i prawnych tego aktu zob. W. Ullmann: The Growth of papal Government in the Middle Ages. A Study in the ideological Relation of clerical to lay Power. London 1962, s. 97-99; P.A. van den Baar: Die kirchliche Lehre der Translatio Imperii Romani bis zur Mitte des 13. Jahrhunderts. Romae 1956, s. 6-14.
} 
ty innych suwerennych pontifexów, nadających poszczególne odkrywane ziemie i wyspy (przy słabości ówczesnej techniki pomiarowej przynależność bywała sporna) któremuś z tych państw ${ }^{147}$.

Robert Bellarmin zdawał sobie sprawę, że te 2 kwestie bardzo komplikują jego wykładnię władzy papieskiej. Gdy współczesny badacz pisze o dzielącej świat bulli Aleksandra VI, że to „jeden z ostatnich aktów wykonywania władzy doczesnej przez papieża"148, to - aby utrzymać swoją doktrynę - jezuita musi dowieść, że tak nie jest. Trudno nam uznać za wystarczającą odpowiedź stwierdzenie, że fakt, iż Aleksander VI podzielił świat między Hiszpanię i Portugalię nic nie znaczy, gdyż w dokumentach tych nie chodziło o podział stref kolonialnych, lecz stref misyjnych, ewangelizacyjnych ${ }^{149}$. Jakkolwiek można interpretować ten podział misyjnie (teza zaczerpnięta zresztą od F. Vitorii ${ }^{150}$ ), to nie zmienia to faktu, że był tożsamy z podzieleniem polityczno-kolonialnym Ameryki, Afryki i Pacyfiku.

Podobnie poświęcona problemowi translacji imperium Bellarminowa rozprawa o tymże tytule (De translatione Romani Imperij, 1584) ${ }^{151}$ nie rozwiązuje sprzeczności pomiędzy nauką Włocha o papieskiej władzy pośredniej - przedstawianą przezeń jako jedynie prawowitą - a praktyką polityczną, gdy Leon III użył władzy bezpośredniej, ustanawiając nowe cesarstwo, czyli zmieniając strukturę polityczną Europy ${ }^{152}$. Jezuita przyznaje, że papież uczynił to „własnym prawem” (iuro suo) ${ }^{153}$, z czego wynika, że suwerenny pontifex jednak władzę doczesną posiada i to wcale nie błahą.

Problemy ustanowienia granic kompetencyjnych pomiędzy rodzącymi się nowożytnymi państwami a uniwersalnym Kościołem są nierozwiązywalne i wynikają z nauki samego Kościoła. Jeśli nauczanie to przyjmuje jako aksjomat wyższość władzy eklezjalnej nad doczesną i moc ekskomunikowania oraz deponowania monarchów, to pojawiają się 2 kwestie problematyczne: 1) co dokładnie wiąże się z kwestiami wiary, moralności

\footnotetext{
${ }^{147}$ P. Castañeda Delgado: La Teocracia pontifical y la conquista de America. Vitoria 1968, s. 249-57.

148 Ibidem, s. 251.

${ }^{149}$ R. Bellarmin: De Romani Pontificis, op.cit, V, 2 (kol. 877CD).

${ }^{150}$ P. Castañeda Delgado: La Teocracia pontifical ..., s. 257-58; W. Buchner: Wojna i konkwista. Hiszpańska myśl polityczna Złotego Wieku. Kraków 2007, s. 211-12.

${ }^{151} \mathrm{O}$ okolicznościach powstania tej polemicznej rozprawy zob. J.L. Orella Unzue: Il concetto di impero romano e il problema della 'translatio' nella polemica tra Flacio Illirico e Bellarmino. [w:] Roma, Costantinopoli, Mosca. Napoli 1983, s. 151-71.

152 R. Bellarmin: De translatione Romani Imperij [1584]. [w:] Idem: Disputationes, op.cit., t. II (kol. 903-84)

${ }^{153}$ Tytuł XII rozdziału De translatione Romani Imperij brzmi: Romanum Pontificem iure suo Imperium à Grecis in Germanos transtulisse i taka też jest wymowa tego fragmentu.
} 
i zbawienia, czyli przynależy do kompetencji władzy pontyfikalnej? 2) W przypadku łatwo przewidywalnej niezgodny pomiędzy dwoma mieczami w kwestii pierwszej, kto podejmuje się rozsądzenia sporu?

Problemy te są trudne, ponieważ w Średniowieczu do kwestii moralnych zaliczano nie tylko sprawy dotyczące jednostek, lecz także związane z zarządzeniem państwem. W ujęciu klasycznym politykę uważano przecież za gałąź moralności (Arystoteles traktował ją jako gałąź etyki). Skoro decyzje polityczne są działaniami moralnymi, to mogą podlegać ocenie pontyfikalnej, a podejmujący je może zostać uznany za tyrana, ekskomunikowany i zdeponowany. Autorzy kościelni (M. Maccarrone, A. Prieto Prieto) lubią podkreślać, że papieska doktryna teokratyczna zawsze starannie rozdzielała sferę doczesną od nadprzyrodzonej i problem kompetencyjny w praktyce nie występował ${ }^{154}$. Pogląd ten jest kontestowany przez badaczy świeckich ${ }^{155}$, także i przez autora poniższej pracy ${ }^{156}$. Zresztą nawet wspomniany przed chwilą bp Michele Maccarrone nie wytrwał w swojej ocenie, uznając ostatecznie, że Innocenty III przypisywał sobie prawo do interwencji w kwestie stricte polityczne „w sytuacji nadzwyczajnej” ${ }^{357}$.

Przypomnijmy, że Innocenty III głosi prawo pontyfikalne do bezpośredniej ingerencji w kompetencje władzy świeckiej z następujących powodów: ciężkiego grzechu popełnionego publicznie (doktryna ratione peccati) ${ }^{158}$; konieczności czuwania nad traktatami pokojowymi1 ${ }^{159}$; „skandalu” politycznego (np. gdy 7 elektorów nie obrało cesarza jednomyślnie, lecz większością głosów) ${ }^{160}$; niezgody pomiędzy Biskupem Rzymu a cesarzem ${ }^{161}$. Przypadek ostatni jest szczególnie interesujący: w sporach na linii papież-monarcha, ten pierwszy sam stawia się w roli sędziego we własnej sprawie, co przyznają czasem nawet filozofowie katoliccy ${ }^{162}$. Kanoniści dodali do kompetencji papieskich także prawo interwen-

\footnotetext{
${ }^{154}$ Kwestię tę akcentują badacze kościelni, np. M. Maccarrone: Chiesa e stato nella dottrina di papa Innocenzo III. Romae 1940, s. 78-107; F. Kempf: Papsttum und Kaisertum bei Innocenz III. Die geistigen und rechtlichen Grundlagen seiner Thronstreitpolitik. Roma 1954, s. 253-79; A. Prieto Prieto: Inocencio III..., s. 233-36.

${ }^{155}$ A. Luchaire: Innocent III. La Papauté et l'Empire. Paris 1906, s. 15.

${ }^{156}$ A. Wielomski: Teokracja papieska..., s. 206-20.

${ }^{157}$ M. Maccarrone: Chiesa e stato..., s. 121-23.

${ }^{158}$ Ibidem, s. 108-25; idem: La papauté et Philippe Auguste. Le décrétale ,Novit ille. [w:] R.H. Bautier (red.): La France de Philippe Auguste. Le Temps des Mutations. Paris 1982, s. 385-408; F. Kempf: Papsttum und Kaisertum..., s. $256-70$.

${ }^{159}$ Innocenty III: Regestorum sive Epistolarum, op.cit., VII, 42.

${ }^{160}$ Innocenty III: Registrum super negotio Romani Imperii. [w:] Patrologia Latina. Paris 1848-49, t. CCXVI, 33.

${ }^{161}$ Ibidem, 179.

162 J. Maritain: Primauté du Spirituel. Paris 1927, s. 43-44, 59.
} 
cji w kwestie polityczne w razie symonii (co akurat jest zrozumiałe), konfliktowości króla $\mathrm{z}$ wasalami i państwami sąsiednimi ${ }^{163}$, a nawet $\mathrm{w}$ przypadku braku podejmowania decyzji politycznych i zainteresowania sprawami państwa (tzw. gnuśność) ${ }^{164}$.

Ostateczny cel Innocentego III był na pograniczu doczesności i religii: zorganizowanie wielkiej krucjaty przeciwko islamowi, aby odzyskać Jerozolimę, w której dowództwo miał objąć papież bezpośrednio, a cesarz i monarchowie mieli w niej występować w roli

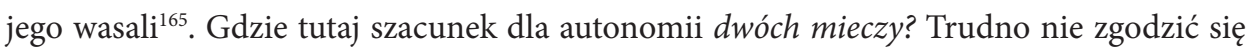
z historykami, że Innocenty III nie był tylko papieżem, lecz jednocześnie twórcą doczesnego panowania na wielkiej przestrzeni kontynentalnej, stając się tym samym „naczelnikiem nowego imperium" (F. Rocquain) ${ }^{166} \mathrm{i}$ będąc ,jednym z najbardziej wszechwładnych władców świata jakich znamy, uznanym przez wszystkich monarchów Europy za verus Imperator chrześcijaństwa" (E. Kantorowicz) ${ }^{167}$.

\section{Sprzeczności u Bellarmina}

Patrząc na interesujący nas problem bronionych przez Roberta Bellarmina 2 interwencji papieskich, wynikłych z władzy jak najbardziej bezpośredniej w sprawy polityczne, widzimy, że z perspektywy historii prawa kanonicznego rozdział władzy pośredniej i bezpośredniej jest kwestią wielce skomplikowaną. Bez wątpienia Bellarmin odmawia Kościołowi tego, co głosili Hostencjusz, Alvaro Pelayo i Augustyn z Ankony, a zrealizował w praktyce Innocenty IV ${ }^{168}$ : prawa do ustawicznego zarządzania państwami i likwidacji autonomii władzy doczesnej, aby zastąpić ją modelem hierokratycznym, gdzie papież traktuje monarchów jako odwoływalnych w każdej chwili legatów. Mamy tutaj na myśli słynną teorię władzy jako beneficjum kościelnego Aleksandra III, zawartą w jego słynnym pytaniu „od kogo cesarz ma więc cesarstwo, jeśli nie od papieża?” (A quo ergo habet, si a domino papa non habet, imperium?) ${ }^{169}$. Hierokratyzm to oczywiście propozycja skrajna. Jezuita

\footnotetext{
${ }^{163}$ O. Hageneder: Il Sole e la Luna. Papato, imperio e regni nella teoria e nella prassi dei secoli XII e XIII. Milano 2000, s. 179-98.

${ }^{164}$ E.M. Peters: Rex inutilis. Sancho II of Portugal and thirteenth century Deposition Theory, "Studia Gratiana", 1967, nr 14, s. 255-305; idem: The Shadow King. Rex Inutilis im Medieval Law and Literature. London 1970, s. $135-69$.

${ }^{165}$ M. Maccarrone: Studi su Innocenze III. Padova 1972, s. 89-92.

${ }^{166}$ F. Rocquain: La Papauté du Moyen Age. Nicolas Ier, Grégoire VII, Innocent III, Boniface VIII. Etudes sur le pouvoir pontifical. Paris 1881, s. 139.

${ }^{167}$ E. Kantorowicz: Frederick the Second, 1194-1250. New York 1957, s. 33.

${ }^{168}$ M. Pacaut: L'autorité pontificale selon Innocent IV, “Le Moyen Age”, 1960, nr 15, s. 85-118.

${ }^{169}$ M. Pacaut: Alexandre III. Etude sur la conception du pouvoir pontifical dans sa pensée et dans son oeuvre. Paris 1956, s. 98-99.
} 
dopuszcza jednak możliwość, że Biskup Rzymu kasuje i ustanawia imperia (translacje) lub dzieli świat pomiędzy Hiszpanię i Portugalię. Są to kwestie zdecydowanie wychodzące poza zakres władzy pośredniej, wiążącej się z prawem ekskomuniki i depozycji króla-heretyka.

Robert Bellarmin nie zachowuje konsekwencji również w swoich rozważaniach teoretycznych. Oto w rozprawie O papieskiej monarchii eklezjalnej mamy księgę V, rozdział 6 , a tutaj 2 ciekawe miejsca, gdzie władza pontyfikalna wprost przekracza charakter pośredni. Pierwszy cytat brzmi:

Papież, z racji bycia papieżem, nie może tak po prostu podyktować praw państwowych lub ich zatwierdzać (...). Ale może to uczynić, jeśli prawo państwowe jest konieczne dla zbawienia dusz (podkr. -A.W.), a królowie nie chca sami go ustanowić, a innego znieśścito.

Zaraz potem mamy drugi cytat:

Papież, z racji bycia papieżem, nie może tak po prostu osadzać kwestii doczesnych (...). Ale w wypadku, gdy jest to konieczne do zbawienia dusz (podkr. -A.W.), kaplan ten może dokonać osądów w kwestiach doczesnych, gdy nie ma nikogo innego, kto może sprawe rozstrzygnąć, gdy dwóch królów nie posiada nad soba nikogo jako wyższego od siebie lub gdy ten, kto powinien dokonać rozstrzygnięcia, z jakiegoś powodu nie chciał tego zrobić. (...) Bo jak stanowi Innocenty III $w$ 'Per venerabilem', $w$ rozdziale 3, to papież może zdecydować którzy synowie sa prawowici, bowiem papież nawet w tej kwestii może wykonywać jurysdykcje doczesna ${ }^{171}$.

Robert Bellarmin uzasadnia te ekstraordynaryjne papieskie uprawnienia wyższością władzy duchowej nad doczesną ${ }^{172}$. Obydwa cytaty zgodnie wskazują, że Biskup Rzymu nie posiada codziennej jurysdykcji nad światem doczesnym, ale gdy wymaga tego konieczność lub sytuacja nadzwyczajna, to papież może - mocą personalnej decyzji - wyjść poza swoje konstytucyjne ograniczenia i dokonać niezbędnego rozstrzygnięcia, niczym decyzjonistyczny suweren z pism Jeana Bodina, Thomasa Hobbesa i Carla Schmitta.

W literaturze przedmiotu nie ma zgodności co do interpretacji problemu relacji między Kościołem a państwem w teorii Bellarmina. Jako pierwszy nad problemem pochylił się w 1934 roku wybitny tomista i neoscholastyk o. Franz X. Arnold, który jednak - raczej mało kompetentny w nauce prawa i w naukach o polityce - chyba nie dostrzegł wskazanej powyżej sprzeczności, mimo że cytowane powyżej 2 fragmenty referuje w swo-

\footnotetext{
${ }^{170}$ R. Bellarmin: De Romani Pontificis, op.cit, V, 6 (kol. 889AB).

${ }^{171}$ Ibidem, V, 6 (kol. 889CD).

172 Ibidem, V, 6 (kol. 887E-888A).
} 
jej rozprawie. Pisze bowiem, że „Bellarmin uznaje, że królowie w kwestiach politycznych są suwerenni” $i$ „władza papieży w rzeczach doczesnych zaprzeczałaby suwerenności”, gdyż „państwo to najwyższa i nikomu nie podlegająca moc” ${ }^{173}$. Twierdzi nawet, że „nie istnieje zasadnicza sprzeczność między suwerennością w rozumieniu Bodina a nauką Bellarmina"174. Jednak po przerzuceniu ponad 200 kolejnych stron jego rozprawy, i po przytoczeniu fragmentów źródłowych o wyjątkowości koniecznych czasami doczesnych interwencji papieskich, czytamy coś zupełnie innego:

W ostatecznym wypadku władza duchowna może i musi, wszelkimi sposobami i środkami ja (władze państwowa - A.W.) zmusić (coercere tempolarem omni ratione ac via, quae ad id necessaria videtur). Papież nie posiada zwykłego (ordinarie) prawa do interwencji w sprawy państwowe, ale jako najwyższy duchowny władca posiada konieczne najwyższe moce wobec kwestii doczesnych, wobec wszystkich chrześcijan, majac na celu bonum spirituale. To jego uprawnienie, aby wtracić się w kompetencje państwowe jest ugruntowane i ograniczone koniecznościa, jest wymuszone troską o zbawienie dusz. Ta 'bezpośrednia' władza papieska nie znosi porzadku politycznego, ani nie miesza go z porzadkiem władzy duchownej, co było konsekwencja teorii hierokratycznej o bezpośredniej doczesnej władzy Kościoła. Chodzi tylko o to, że papież moca swojej duchowej i apostolskiej władzy ma prawo kierować lub korygować władze polityczna, gdy jest to konieczne dla celu duchowego, na przykład przenoszac panowanie z jednego władcy na drugiego. Ta moc czyni zeń mózg całego chrześcijaństwa, nadzorcę całej chrześcijańskiej rodziny i głowę catego ciała do którego przynależy także cesarz i królowie ${ }^{175}$.

Pogląd o prawomocności podporządkowania państwa Kościołowi można oczywiście głosić i ma on swoje solidne religijne uzasadnienie, podane zresztą przez o. Arnolda, który uzasadnia tę nierówność „organicznym związkiem obydwu władz”, gdzie „państwo jest materią a Kościół formą"176, szczególnie zaś dowodząc, że celem człowieka nie jest szczęście doczesne (sfera państwowa), lecz zbawienie (sfera eklezjalna) ${ }^{177}$. Pozostaje jednak dla nas zagadką jak pogląd ten połączyć z przekonaniem, że prawo do nadzwyczajnych interwencji doczesnych nie godzi w zasadę suwerenności państwa głoszonej przez Jeana Bodina?

\footnotetext{
${ }^{173}$ F.X. Arnold: Die Staatslehre des Kardinals..., s. 103, 105.

${ }^{174}$ Ibidem, s. 107.

175 Ibidem, s. 349-50.

${ }^{176}$ Ibidem, s. 350-51.

${ }^{177}$ Ibidem, s. 353-56.
} 
W późniejszej literaturze problem ten dostrzeżono i wywołał ożywioną dyskusję. W literaturze zarysowały się 2 stanowiska:

1) Pogląd teokratyczny. Francuski badacz Bernard Bourdin uważa, że Bellarmin był głęboko przywiązany do mediewalnej teorii papalistycznej i był niechętny nowoczesnemu, wyemancypowanemu od Kościoła państwu, ale zdawał sobie sprawę, iż otwarte roszczenia hierokratyczne są nierealne politycznie w dobie Reformacji. Dlatego zaproponował opcję umiarkowaną w postaci władzy pośredniej: „Zgodnie z duchem Towarzystwa Jezusowego jest całkowicie wierny papiestwu”, ale zarazem „stara się o uniknięcie tez ekstremalnych o władzy bezpośredniej papieża w rzeczach doczesnych, jak i władzy monarchów w rzeczach duchowych"178.

Tezę Bourdina o kompromisowości tego rozwiązania podziela włoski badacz Vittorio Frajese, uważający, że jest to rozwiązanie kompromisowe pomiędzy teokracją a państwem suwerennym, wypracowane jeszcze na przełomie XV i XVI wieku przez Juana de Torquemadę i Francisco Vitorię $e^{179}$. W sumie, zdaniem obydwu badaczy, jezuita nie był zdolny do uznania całkowitej emancypacji państwa. Bourdin tak charakteryzuje jego pogląd:

W porzadku naturalnym poddani sa podporzadkowani swoim władcom, a w porządku nadnaturalnym winni posłuszeństwo władzy eklezjalnej. Pomimo wspótprzenikania się porzadku doczesnego i duchowego, i mimo tożsamości poddanych w tym samym chrześcijańskim porządku państwowym, sa oni zobowiąani do postuszeństwa wobec władzy politycznej jako członkowie ciała społecznego a nie jako chrześcijanie. Ale są także, niezależnie od obowiązku posłuszeństwa władzy politycznej, zobowiązani do wierności papieżowi ${ }^{180}$.

Z konstrukcji tej wynika dwuwładza, jednoczesne podporządkowanie poddanego/wiernego monarsze w kwestiach politycznych i papieżowi w kwestiach religijnych. Ale komu poddany/wierny ma być posłuszny w kwestiach mieszanych, którymi zainteresowane są i państwo i Kościół? Biegły w historii, prawie rzymskim i kanonistyce jezuicki teolog dobrze wiedział, że suwerenność jest niepodzielna i jedna z władz musi dominować nad drugą, pod groźbą wojny domowej. Ukazywała tę konieczność historia reformy gregoriańskiej (konflikt papieża z cesarzem), jak i nowożytna teoria państwa. Bourdin słusznie wskazuje, że Bellarmin nie waha się i stoi na następującym stanowisku:

\footnotetext{
${ }^{178}$ B. Bourdin: La genèse théologico-politique..., s. 113-14.

${ }^{179}$ V. Frajese: Una teoria della censura: Bellarmino e il potere indiretto dei papi, „Studi Storici”, 1984, s. 139-52. Podobne poglądy R. Bellarmina i F. Vitorii odnośnie władzy pośredniej papieża dostrzega także E. Naszalyi: El Estado segun Francisco de Vitoria. Madrid 1948, s. 128-30.

${ }^{180}$ B. Bourdin: La genèse théologico-politique..., s. 119.
} 
Najważniejszym celem człowieka, któremu wszystko winno zostać podporzadkowane, jest szczęście wieczne. Do tego zaś szczęścia prowadzi tylko religia, a więc kapłani, wykonawcy celu nadrzędnego, mający w konsekwencji władzę najwyższa nad ludźmi. Władza ta nie dotyczy tylko poszczególnych jednostek, lecz także wspólnot politycznych, gdyż to, co dotyczy tych pierwszych, dotyczy także i tych drugich. Władza wynika z religii i obejmuje wszystko, co tylko dotyczy religijnych interesów, ale nic poza tym. Wszędzie, gdzie jest interes religijny, tam władza duchowa ma prawo zarządzać, a jej kompetencje kończa się tam, gdzie kończy się interes religii ${ }^{181}$.

2) Pogląd hierokratyczny. Kompromisowość formuły władzy pośredniej Roberta Bellarmina - jako złotego środka pomiędzy hierokratyzmem a regalizmem - była poddawana $\mathrm{w}$ wątpliwość już pod koniec XIX wieku ${ }^{182}$, ale problem na dobre podnieśli dopiero liberalni katolicy francuscy w latach trzydziestych i czterdziestych XX stulecia ( $\mathrm{H}$. de Lubac, J. Lecler), widzący w niej zamaskowaną hierokrację pontyfikalną ${ }^{183}$. Jednakże jako pierwszy problem starannie przebadał i dokonał takiej też interpretacji Bellarmina kanadyjski jezuita o. John Courtney Murray w 1948 roku, traktujący jego naukę o stosunku Kościoła do władzy politycznej jako pretekst do krytyki tradycyjnego Magisterium w tym względzie ${ }^{184}$. Jakkolwiek Bellarmin stanowi pretekst do prezentacji własnych poglądów, to tekst Murray’a zawiera interesujące spostrzeżenia o nauce włoskiego jezuity o stosunkach między papiestwem a nowożytnym państwem.

Zdaniem o. Murray’a, Robert Bellarmin nie potrafił oderwać się od mediewalnego teokratycznego postrzegania świata doczesnego. Jakkolwiek, za Akwinatą, teoretycznie raz po raz podkreśla odrębność państwa i Kościoła, to ten ostatni dominuje całkowicie nad doczesnością. Jako pewnik zakłada, że model gregoriański Innocentego III stanowi ponadczasowy archetyp relacji obydwu władz, nie dostrzegając jego historycznego i niepowtarzalnego charakteru (błąd określany przezeń mianem "fixism"185). Siła rażenia Bellarminowej nauki w XVI-XVII wieku, dowodzi Murray, wynikała z faktu, że jego

\footnotetext{
${ }^{181}$ Ibidem, s. 119-20.

${ }^{182}$ F. Moulart: L'Eglise et l'Etat. Paris 1887, s. 195.

${ }^{183}$ H. de Lubac: Le pouvoir de l'Eglise en matière temporelle, „Revue des Sciences Religieuses“, 1932, nr 12, s. 335; J. Lecler: L'Eglise et la souveraineté de l'Etat. Paris 1944, s. 101-04.

${ }^{184}$ J. Courtney Murray był uznanym specjalistą od stosunków państwo-Kościół na Soborze Watykańskim II. Krytycy reform soborowych widzieli w nim osobę odpowiedzialną za przyjęcie dokumentów soborowych głoszących słuszność rozdziału obydwu instytucji na wzór amerykański, potępiony przez Leona XIII (M. Davies: Sobór Watykański II a wolność religijna. Warszawa 2002, s. 81-117).

185 J.C. Murray: St. Robert Bellarmin..., s. 523 (autor tego tekstu, jako modernista, z tymże poglądem wchodzi w radykalną polemikę, prezentując stanowisko klasyczne historycystyczne (s. 523-35).
} 
archetypiczny model gregoriański został zbudowany wyłącznie za pomocą argumentacji racjonalistycznej, bez elementu fideistycznego i dlatego zrobił tak mocne wrażenie na nowożytnych umysłach, a jego argumenty wciąż porażają swoją logiką. Fideistyczne teorie protestanckich polemistów Bellarmina zupełnie nie przemawiają już do naszej umysłowości i dlatego wydają się nam intelektualnie żałosne ${ }^{186}$. Ale za tą czysto racjonalną argumentacją i metodą dowodzenia - przekonuje nas Murray - kryje się wizja całkowicie mediewalna: Bellarmin traktuje państwo i suwerenów jedynie jako część Kościoła, a nie jako byt odrębny ${ }^{187}$. Stoi na stanowisku gregoriańskim, że w ręku Biskupa Rzymu są $d$ wa miecze $e^{188}$. Dlatego heretyków (także królów-heretyków) traktuje wyłącznie jak buntowników. Dlatego także swój ważny traktat o władzy politycznej Bellarmin zatytułował O laikacie. Sama nazwa subordynuje monarchę-laika pod władzą duchowną, wpisując się $\mathrm{w}$ średniowieczną wizję świata ${ }^{189}$.

W sumie o. John Courtney Murray twierdzi, że z powodu znanych nam już wyjątkowych uprawnień papieskich do interwencji w sprawy polityczne i prawne, należy uznać Roberta Bellarmina - mimo skrajnie racjonalistycznej (nowoczesnej) narracji - za mediewalnego teokratę, który nie chce otwarcie dokonać swojej autentycznej samoidentyfikacji. To czy interwencje papieskie są normalnie uprawnione czy też mają charakter nadzwyczajny nie ma dla Murray’a żadnego znaczenia, gdyż 1 wyjątek skutecznie obala ogólną regułę ${ }^{190}$. Z tego też powodu włoski jezuita - twierdzący, że zachowuje złoty środek między hierokratami a regalistami i zwolennikami Boskich praw królów - gros swojego zainteresowania poświęca polemice z tymi ostatnimi, gdy z pierwszymi polemizuje w swoich dziełach, gdyby fragmenty te zebrać w jedną całość, na przestrzeni kilku stron ${ }^{191}$.

Podobnie wnioskuje włoska badaczka Enrica Fabbri, która w cytowanych przez nas powyżej fragmentach z rozdziału 6 księgi V O papieskiej monarchii eklezjalnej dostrzega „zamaskowaną potestas directa”, która „nie jest czystą i prostą władzą duchową, stając się formalnie doczesną, zdolną do modelowania kształtu polityki”'192. Fabbri uważa, że owo zamaskowanie jest charakterystyczne „tak jak u hierokratów, wobec władzy zarezerwowanej

\footnotetext{
${ }^{186}$ Ibidem, s. 503-04.

${ }^{187}$ Ibidem, s. 511-15.

${ }^{188}$ Ibidem, s. 516.

${ }^{189}$ Ibidem, s. 507.

${ }^{190}$ Ibidem, s. 499-501.

${ }^{191}$ Ibidem, s. 504-06.

${ }^{192}$ E. Fabbri: Roberto Bellarmino e Thomas Hobbes. Teologie politiche a confronto. Roma 2009, s. 49.
} 
do użytku wyjątkowego. Pomiędzy obydwoma teoriami (władzą pośrednią i bezpośrednią - A.W.) wielu interpretatorów dostrzegało różnice bardziej pozorne niż rzeczywiste"193. W praktyce bowiem, powołując się na wyjątkowość sytuacji, suwerenni pontifexi zawsze mogą dokonać interwencji w materię państwową. Fabbri pisze:

W refleksji jezuickiego teologa, przynależność do Kościoła staje się zasadą absorpcji tego, co doczesne przez to, co duchowe, bowiem w jednym ciele zwanym 'respublica christiana' cele polityki ziemskiej traca swoja wtasna autonomie, stając się podporzadkowanymi dobru chrześcijaństwa. Zachowują swoją wartość na tyle, na ile nie stoją w sprzeczności z tym pierwszym, schodzac do rangi narzędzi dla dóbr duchowych ${ }^{194}$.

Ostatecznie Enrica Fabbri konkluduje, że z logiki Bellarminowej winna zrodzić się teza charakterystyczna dla augustynizmu politycznego, że władza polityczna pochodzi z nadania Kościoła. Jezuita tezy takiej nie przedstawia z racji swojego tomistycznego i scholastycznego wykształcenia. Tylko ono nakazuje mu zachować mocno fikcyjną autonomię sfery doczesnej ${ }^{195}$. Gdy zdejmiemy z Bellarmina tomistyczną maskę - dowodzi włoska badaczka - to zobaczymy w nim hierokratę, który zaprzecza podstawowemu dogmatowi Nowożytności, że podstawowym podmiotem politycznym jest suwerenne państwo, oparte na prawie natury. Jezuita widzi w europejskich stosunkach międzynarodowych tylko jeden jedyny i wszechogarniający podmiot: jest nim Kościół katolicki jednoczący w jednym ręku władzę duchową i polityczną ${ }^{196}$.

Podobnie sądzi Franco Motta, który w eklezjologii Bellarmina, sprowadzającej sobór do rangi „rodzaju papieskiej kancelarii”, dostrzega próbę „sakralizacji postaci papieża"197, której następstwem jest idea etatyzacji struktury Kościoła, czyli przekształcenia go w rodzaj duchowego i duchownego super-państwa. Jest to niezależna i scentralizowana struktura znajdująca się wewnątrz państw katolickich, próbująca je zdominować i podporządkować swojej woli. Cechą specyficzną tej renesansowej konstrukcji jest oparcie jej nie na cudach i fideizmie, lecz na prawie, gdzie papież-suweren posiada władzę ustawodawczą, wykonawczą i sądowniczą nad chrześcijańskim światem ${ }^{198}$. Mimo to Motta obstaje przy tezie, że u Bellarmina rozdział pomiędzy sferą doczesną a duchowną zostaje w jakiejś mierze

\footnotetext{
193 Ibidem, s. 49.

${ }^{194}$ Ibidem, s. 50.

195 Ibidem, s. 53-55.

${ }^{196}$ Ibidem, s. 56.

${ }^{197}$ F. Motta: Bellarmino, op.cit., s. 379, 380.

${ }^{198}$ Ibidem, s. 383-84.
} 
zachowany z tej racji, że jezuita wielokrotnie powtarza, iż papież posiada władzę wyłącznie nad monarchami chrześcijańskimi i nie ma jej nad pogańskimi. Gdyby Biskup Rzymu zniósł to rozróżnienie, to rzeczywiście mógłby sprawować władzę nad całym światem w sposób bezpośredni, a jezuita takiej możliwości nie przewiduje ${ }^{199}$. Zniesienie rozróżnienia dotyczy tylko świata chrześcijańskiego i możemy mówić tylko o terytorialnej hierokracji.

Do tej dyskusji musimy się odnieść. Stoimy na stanowisku następującym: w zasadzie Robert Bellarmin akceptuje sytuację, że nowożytne państwo posiada monopol na podmiotowość w stosunkach międzynarodowych, o ile będzie to państwo katolickie. Pozostawia jednak w rękach suwerennego pontifexa prawo do ekstraordynaryjnych interwencji w domenę jednoznacznie doczesną i polityczną, implicite zakładając, że papież sam i subiektywnie decyduje kiedy konieczność taka istnieje i kiedy musi przeistoczyć się w suwerennego sędziego świata politycznego. Państwo nowożytne jest na codzień suwerenne, ale znajdujący się w innym porządku ontologicznym papież cieszy się tradycyjną prerogatywą swoistej nad-suwerenności nad światem chrześcijańskim.

Teoretycznie zasada jest prosta i przypomina teorię decyzjonizmu Carla Schmitta zastosowaną jednak tym razem nie do konstytucji Republiki Weimarskiej, lecz do konstytucji katolickiej Europy. Użycie władzy pośredniej zostało przez Bellarmina opisane jasno: papież używa ekskomuniki i depozycji w sytuacji herezji i apostazji suwerena z Kościoła katolickiego, czyli w nadzwyczajnej sytuacji teologiczno-politycznej. Ale władza bezpośrednia Biskupa Rzymu rysuje się nam bardzo mgliście. Problemem jest oczywiście brak opisania sytuacji możliwego jej zastosowania czy to przez międzynarodowe prawo publiczne czy to przez prawo kanoniczne. Zamiast prawniczych definicji znajdujemy tylko 2 historyczne przykłady i 2 cytaty odnośnie ogólnej reguły.

Czy można uchronić zasadę nadzwyczajnych papieskich interwencji bezpośrednich przed niebezpieczeństwem arbitralności? Opisanie wszystkich możliwych sytuacji wyjątkowych w prawie międzynarodowym lub kanonicznym oczywiście nie jest możliwe, chyba, że ograniczymy się - jak to czyni właśnie Robert Bellarmin - do ogólnych haseł obrony chrześcijaństwa, walki z herezją lub zapobieżenia apostazji. Ktoś jednak zawsze musi

\footnotetext{
199 Ibidem, s. 429. Punkt ten uważamy za bardzo istotny, wziąwszy pod uwagę, że mediewalne roszczenia papieskie (Innocenty IV) do bezpośredniej władzy nad światem opierały się na przekonaniu, że podlegają mu i chrześcijanie i poganie - zob. W. Ullmann: Medieval Papalizm. The Political Theories of the Medieval Canonists. London 1949, s. 119-33; O. Hageneder: Kirche und Christenheit in der neuen Ekklesiologie des Papsttums. [w:] G. Andenna (red.): Pensiero e sperimentazioni istituzionali nella „Societas Christiana” (1040-1250). Milano 2007, s. 223, przypis 35 .
} 
dokonać osądu czy konieczność odwołania się do któregoś z tych ogólnych pojęć już zaistniała czy też mamy do czynienia jedynie z mglistym zagrożeniem hipotetycznym? W roli Schmittiańskiego suwerena całej chrześcijańskiej Europy Bellarmin widzi rzymskiego pontifexa, który w chwili egzystencjalnego zagrożenia, mocą personalnej decyzji, z wysokości Tronu św. Piotra, jako Wikariusz Chrystusa, będący jedyną władzą ziemską pochodzącą bezpośrednio od Boga (bez pośrednictwa ludu) dokonuje interwencji w kwestie polityczne, które w normalnej sytuacji nie należą do jego kompetencji. Mocą własnej, personalnej i subiektywnej decyzji renesansowy pontifex przeistacza się w antycznego Pontifexa Maximusa, który, niczym królowie rzymscy sprzed wygnania Tarkwiniuszy i późniejsi cezarzy, jednoczy w swoim ręku suwerenność duchową i polityczną.

Kanoniści tradycyjnie ujmowali suwerenność papieską pod postacią 2 sentencji: papież nie jest osądzany przez nikogo (prima sedes a nemine iudicatur) i, zaczerpniętej z prawa rzymskiego publicznego, formuły władca jedynym prawodawca (princeps legibus solutus $)^{200}$. Nie przywołując explicite tych formuł Bellarmin je akceptuje, acz bardzo mocno zastrzega tylko dla sytuacji naprawdę ekstraordynaryjnych. Zauważmy, że jezuita ani słowem nie wspomina, aby w epoce Reformacji i wojen religijnych - czyli w sytuacji dla katolicyzmu naprawdę ekstremalnej - zaistniała potrzeba odwołania się papieża do jego nadzwyczajnej władzy bezpośredniej. Dlatego nie zgadzamy się z poglądem wyrażanym przez o. Murray’a, że pojedynczy wyjątek unieważnia regułę generalną jako taką. Bellarmin tak nie myślał, ponieważ w ten sposób nie myślano w jego epoce. Przypomnijmy w tym miejscu słynną scholastyczną dysputę: czy jeśli wyrzucony na brzeg rozbitek jest głodny i wycieńczony, to czy mu wolno zerwać owoc z cudzego drzewa i zjeść go? Neoscholastycy stali na stanowisku, że istnieje hierarchia celów i zachowanie życia ma pierwszeństwo nad bezwzględnie pojętym prawem własności. Dla liberałów, myślących całkowicie nowożytnie, stanowi to naruszenie zasady świętej własności prywatnej. Tymczasem scholastycy w ogóle nie dostrzegali tego niebezpieczeństwa, gdyż rozważali sytuację ekstraordynaryjną i nie uznawali jej za normalną ${ }^{201}$. Bellarmin identycznie zdaje się pojmować problem ekstraordynaryjnych interwencji papieskich, gdyż ratunek Kościoła stoi w hierarchii celów wyżej niż zasada regalistyczna.

\footnotetext{
${ }^{200}$ D. Wyduckel: Princeps legibus solutus. Eine Untersuchung zur frühmodernen Rechts- und Staatslehre. Berlin 1979, s. 94-101; S. Vacca: Prima sedes a nemine iudicatur. Genesi e sviluppo storico dell'assioma fin al Decreto di Graziano. Roma 1993.

${ }^{201}$ A.A. Chafuen: Wiara i wolność. Myśl ekonomiczna późnych scholastyków. Warszawa 2007, s. 57-64.
} 


\section{$6 / 2017$}

\section{Reakcje i polemiki}

\section{Stanowiska katolickie}

Pogląd Roberta Bellarmina jakoby suwerenny pontifex miał prawo do depozycji królów, a w istocie także moc wszelkiej interwencji w kwestie polityki doczesnej w sytuacji ekstraordynaryjnej, wywołał w Europie głębokie poruszenie. Nie były to bowiem teorie nikomu nieznanego teologa. Gdy jezuita wydał swoją pracę O papieskiej monarchii eklezjalnej to nie był co prawda jeszcze znanym teologiem, lecz dzieło to wydane zostało jako część opasłej trzytomowej rozprawy Dyskusje. O kontrowersjach dotyczacych wiary, przeciwko wspótczesnym heretykom (Disputationes. De controversiis christianae fidei, adversus huius temporis Haereticos, 1581-83), która przyniosła mu duży rozgłos i uznanie, czyniąc zeń czołowego tzw. kontrowersistę, czyli wytrawnego polemistę teologiczno-politycznego ${ }^{202}$. Z kolei rozprawa polemiczna przeciwko Williamowi Barclay’owi, została opublikowana w 1610 roku, gdy Bellarmin był już znany w całej Europie.

Jakkolwiek, naszym zdaniem, rozprawy Roberta Bellarmina w materii papalistycznej stanowią jedynie przypomnienie i unowocześnienie wcześniejszej nauki gregoriańskiej, szczególnie zaś dekretalistyki Innocentego III, to jego pisma dotyczące władzy papieskiej wywołały burzę polityczną w całej Europie. Stało się tak dlatego, że teokratyczna w swojej wymowie kanonistyka Innocentego III została przypomniana prawie 400 lat po śmierci tego wielkiego Biskupa Rzymu, w sytuacji, gdy Europa przeżywała pierwszą falę sekularyzacji (Renesans), a połowa chrześcijan i chrześcijańskich monarchów wypowiedziała Kościołowi posłuszeństwo (Reformacja).

Pisarze Kontrreformacji, a szczególnie jezuici, cytowali pisma Bellarmina traktując je jako wzorcowe dla ortodoksyjnej katolickiej myśli politycznejeㄹ. Stawiano je obok hiszpańskiego jezuity Francisco Suareza, podobnie podporządkowującego nowożytne państwo Kościołowi i głoszącego połączenie suwerenności nowożytnego państwa w sferze politycznej z jednoczesnym pontyfikalnym prawem do depozycji króla-heretyka ${ }^{204}$. Nauczanie to jeszcze na początku XIX wieku przypomniał francuskojęzyczny tradycjonalista Joseph de Maistre w swojej wielkiej rozprawie O papieżu (1821), gdzie powołując się

\footnotetext{
202 J. Brodrick: Robert Bellarmin. L'humaniste et le saint. Bruges 1963, s. 50-81.

${ }^{203}$ Zob. np. G. Fuligatti: Vita del Cardinale Robert Bellarmin. Roma 1624, s. 211-12.

${ }^{204}$ H. Rommen: La teoria del Estado ..., s. 403-46; J.M. Gallegos Rocafull: La Doctrína Política..., s. 297-311; F.P. Cavanan: Subordination of the State to the Church according to Suarez, "Theological Studies", 1951, nr 12, s. 356-64.
} 
właśnie na Bellarmina, odtworzył teorię papieża jako suwerena chrześcijańskiej Europy, opartą między innymi na jego uprawnieniu do ekskomuniki i depozycji monarchów ${ }^{205}$.

Mimo to na przełomie XVI i XVII wieku radykalni hierokraci kiwali z niezadowolenia głowami, domagając się wprost wyłożonej doktryny, że Biskup Rzymu ma władzę bezpośrednią nad całym światem chrześcijańskim. Otwarte ataki na Bellarmina ze strony katolickiej w zasadzie nie miały miejsca, gdyż stała za nim potężna struktura Towarzystwa Jezusowego, za wyjątkiem wspomnianego wcześniej radykalnego papieża Sykstusa V. Papież ten, właśnie z powodu odmowy formalnego uznania papieskiej władzy bezpośredniej, podejrzewał Bellarmina o herezję i nakazał komisji Indexu wciągnąć tom pierwszy Dysput (zawierający tekst $O$ papieskiej monarchii eklezjalnej) na listę książek zakazanych. Mimo papieskiej wszechwładzy, napotkał jednak na silny sprzeciw jezuitów i komisji opracowującej Index, która jednogłośnie sprzeciwiła się papieżowi, uznając dzieło za całkowicie ortodoksyjne (1590). Nie wiadomo jak sprawa potoczyłaby się dalej, ale zaraz po tej decyzji Sykstus V zmarł, a sprawa została wycofana natychmiast przez jego następcę na Stolicy Piotrowej ${ }^{206}$.

\section{Krytyki w gallikańskiej Francji}

Krytyka od strony hierokratycznej to jednak wyjątek. Teorie Bellarmina zostały zaatakowane przede wszystkim przez regalistów i zwolenników zasady absolutnej suwerenności państwa, którzy polemizowali z jego poglądami jako z największą herezją polityczną swojej epoki. Dyskusja ta miała poziom bardzo rozmaity. Zwykle była merytoryczna, lecz w bezwzględnej walce używane były i najgorsze paszkwile. Kolportowano plotki na temat chciwości jezuity, jego rzekomego wyuzdania seksualnego i skrytobójczych mordów na byłych kochankach ${ }^{207}$, a przede wszystkim stwarzano atmosferę zagrożenia, że w myśl nauki Bellarmina papież będzie chciał rzucić do rebelii katolików i objąć bezpośrednie rządy nad państwem. Ten ostatni motyw jest szczególnie charakterystyczny dla pamflecistów francuskich ${ }^{208}$.

W gallikańskiej, choć przecież katolickiej Francji, sądy królewskie zakazywały rozpowszechniania pism Roberta Bellarmina, traktując jego teorię władzy pontyfikalnej

\footnotetext{
${ }^{205}$ J. de Maistre: O papieżu. Kraków 1853 [1821].

${ }^{206}$ X.-M. Le Bachelet: Bellarmin à Index. Documents nouveaux, „Etudes”, 1907, nr 44, s. 227-46; J. Brodrick: Robert Bellarmin, op.cit., s. 93-98; V. Frajese: Una teoria della censura, op.cit..

${ }^{207}$ A.M.D.G.: Święty Robert Bellarmin T.J. Kraków 1930, s. 157.

${ }^{208}$ Najbardziej znane paszkwile to: E. Pasquier: Catéchisme des Jésuites. Paris 1602; A. de Montreal: Le premier coup de retraité contre le tocsin sonné par la statue de Memnon. Contre le livre du Cardinal Ballarmin Jesuite. Montpellier 1611.
} 
jako zagrożenie dla bezpieczeństwa państwa, nawoływanie do katolickiego buntu, a w efekcie nakazywały publiczne palenie dostępnych egzemplarzy. Parlament Paryża, nakazując takąż procedurę, dostrzegł w dziele przeciwko Barclay’owi obrazę królewskiego Majestatu i nawoływanie do buntu wobec „władz suwerennych ustanowionych przez Boga”209. Polemizują z jezuickimi teoriami na temat władzy pontyfikalnej w Kościele i w kwestiach doczesnych znani gallikańscy kanoniści (S. Vigor, E. Le Noble de Tennelière, E. du Pin, P. Dupuy, D. de Maillane, P. Pithou, J. Bossuet), na gruncie politycznym będący zwolennikami podporządkowania Kościoła lokalnej absolutnej monarchii wywodzonej bezpośrednio z woli Boga, a w eklezjologii związani z tradycją koncyliarystyczną ${ }^{210}$.

\section{Krytyki angielskie}

W protestanckiej Anglii polemizuje z poglądami Bellarmin sam król, a zarazem następca uzurpatorów eklezjalnej funkcji głowy kościoła, Jakub VI/I, głoszący doktrynę Boskiego prawa królów, czyli bezpośredniego pochodzenia władzy monarszej od Boga, bez pośrednictwa ludu i jakiejkolwiek wspólnoty religijnej ${ }^{211}$. Wtórują mu nieco późniejsi angielscy pisarze polityczni, których pisma zapowiadają sekularyzację wyspiarskiej myśli politycznej. Wymienić tu trzeba głównego filozofa politycznego monarszego absolutyzmu epoki Stuartów Roberta Filmera, widzącego w Bellarminie i Suarezie rodzaj rewolucyjnych demokratów, podważających władzę monarszą swoimi teoriami o pochodzeniu władzy z woli ludu ${ }^{212}$. Przede wszystkim zaciekłym oponentem Bellarmina okazał się Thomas Hobbes, przenoszący ostatecznie dyskusję z jezuitą na inny poziom i do nowej narracji politycznej. Poddając w wątpliwość istnienie chrześcijańskiego Boga, tym samym stawia pod znakiem zapytania jakąkolwiek władzę jakiegokolwiek kościoła i jego naczelnika ${ }^{213}$.

${ }^{209}$ Extrait des registres du Parlament de Paris. Contre le livre intitulé 'Tractatus de potestate Summi Pontificis in rebus temporalibus adversus Gulielmum Barclaium', auctore Robert Sancte Ecclesia Romanae Cardinali Bellarmin. Paris 1610, s. 3-4.

${ }^{210}$ S. Vigor: Quatre livres de l'Estat et gouvernement de l'Eglise. Troyes 1622, s. 243-62; E. Le Noble de Tennelière: L'Esprit de Gerson ou instructions catholiques touchant le Saint Siège. B.m.w. 1691, s. 40-41, 119-55, 199-233; E. du Pin: Traité de la puissance ecclesiastique et temporelle. Paris 1707, s. 336-39, 350-65; P. Dupuy, D. de Maillane, P. Pithou: Les Libertez de l'église gallicane. T. I. Lyon 1771, s. 17n.; J. Bossuet: Défence de l'église..., s. 289. ${ }^{211}$ James VI /I: Triplici Nodo. Triplex Cuneus, Or an Apologie for the Oath of Allegiance [1608]. [w:] Idem: Political Writings. Cambridge 2006, s. 98-131. Podobną argumentację znajdujemy w pracy J. Battely: The Notes of the Church as Laid down by Cardinal Bellarmin; Examined and Confuted. London 1688, s. 281-89.

${ }^{212}$ R. Filmer: Patriarcha. The Naturell Power of Kinges Defended against the Unnatural Liberty of the People. By Arguments Theological, Rational, Historical, Legall [1680]. [w:] Idem: Patriarcha and others Writings. Cambridge 1991, s. 5-24.

${ }^{213}$ T. Hobbes: Lewiatan, czyli materia, forma i władza państwa kościelnego i świeckiego. Warszawa 1954 [1651], III, 42 (s. 438-523). 
W filozofii politycznej Hobbesa następuje neutralizacja teorii Roberta Bellarmina. Kończąc dyskurs religijny, zakopuje głęboko pod ziemię kwestię władzy bezpośredniej i pośredniej papieża. Angielski filozof zna już tylko suwerenne państwo i prawo natury w świecie, w którym Bóg znikł z horyzontu.

\section{Bibliografia}

\section{Dokumenty:}

Extrait des registres du Parlament de Paris. Contre le livre intitulé 'Tractatus de potestate Summi Pontificis in rebus temporalibus adversus Gulielmum Barclaium', auctore Robert Sancte Ecclesia Romanae Cardinali Bellarmin. Paris 1610.

Haec sancta [1415]. [w:] A. Baron, H.Pietras (red.): Dokumenty soborów powszechnych. T. III. Kraków 2005.

Przywilej Fryderyka II dla książąt niemieckich z 1232 roku. [w:] B. Lesiński, J. Walachowicz: Historia ustroju państwa w tekstach źródłowych. Warszawa-Poznań 1992.

\section{Teksty źródłowe:}

J. Althusius: Politica Methodice digesta atque exemplis sacris \& profanis illustrata. Herbornae Nassoviorum 1614 [1610].

Arystoteles: Polityka. Warszawa 2002.

Augustyn z Ankony: Summa de potestate ecclesiastica. Romae 1584.

W. Barcley: Traité de la Puissance du pape sur les princes seculiers [De potestate papae, an et quantenus in reges et principes saeculares jus et imperium habeat]. Cologne 1687 [1607].

J. Battely: The Notes of the Church as Laid down by Cardinal Bellarmin; Examined and Confuted. London 1688.

R. Bellarmin: De laicis sive secularibus [1589]. [w:] Idem: Disputationes. De controversiis christianae fidei, adversus huius temporis Haereticos. T. II. Parisiis 1608.

R. Bellarmin: De officio primario Summi Pontificis. [w:] Auctarium Bellarminianum. Paris 1913.

R. Bellarmin: De Romani Pontificis ecclesiastica monarchia [1586]. [w:] Idem: Disputationes. De controversiis christianae fidei, adversus huius temporis Haereticos. T. II. Parisiis 1608.

R. Bellarmin: Tractatus de potestate Summi Pontificis in repubus temporalibus adversus Gulielmum Barclaium. Monachij 1712 [1610].

R. Bellarmin: De translatione Romani Imperij [1584]. [w:] Idem: Disputationes. De controversiis christianae fidei, adversus huius temporis Haereticos. T. II. Parisiis 1608.

R. Bellarmin: De Verbo Dei [1586]. [w:] Idem: Disputationes. De controversiis christianae fidei, adversus huius temporis Haereticos. T. I. Parisiis 1608. 
Benedykt XII: Super quibusdam [1349]. [w:] H. Denzinger (red.): Enchiridion Symbolorum. Monachii 1908.

J. Bossuet: Défence de léglise gallicane [Defensio Declarationis celeberrimae, quam de potestate ecclesiastica sanxit Clerus Gallicanus]. Paris 1845 [1730].

F. Bozio: De temporali ecclesiae monarchia. Coloniae 1602.

C. Le Bret: De la souveraineté de Roy. Paris 1689 [1632].

G. Buchanan: Jure Regni apud Scotos, or a Dialogue Concerning the due Priviledge of Government In the Kingdom of Scotland [Jure Regni apud Scotos]. London 1689 [1579].

G. Budé: De l'institution du Prince. Paris 1547.

J. Calvin: Institutes of the christian religion. Peabody 2009 [1581].

J. Calvin: Institution de la Religion chrétienne. Paris 1888.

T. Campanella: Monarchia Messiae. Torino 1960 [1633].

M. Cano: Locis theologicis. Salamanca 1562.

P. Dupuy, D. de Maillane, P. Pithou: Les Libertez de l'église gallicane. T. I. Lyon 1771.

R. Filmer: Patriarcha. The Naturell Power of Kinges Defended against the Unnatural Liberty of the People. By Arguments Theological, Rational, Historical, Legall [1680]. [w:] Idem: Patriarcha and others Writings. Cambridge 1991.

G. Fuligatti: Vita del Cardinale Robert Bellarmin. Roma 1624.

T. Hobbes: Lewiatan, czyli materia, forma i władza państwa kościelnego i świeckiego. Warszawa 1954 [1651].

Innocenty III: Regestorum sive Epistolarum. [w:] Patrologia Latina. T. CCXIV. Paris 1848-49.

Innocenty III: Registrum super negotio Romani Imperii. [w:] Patrologia Latina. T. CCXVI. Paris 184849.

James VI /I: Triplici Nodo. Triplex Cuneus, Or an Apologie for the Oath of Allegiance [1608]. [w:] Idem: Political Writings. Cambridge 2006.

Junius Brutus (Ph. Duplessis-Mornay, H. Languet?): De la puissance legitime du prince sur le peuple, et du peuple sur le Prince [Vindiciae Contra Tyrannos sive, de principis in Populum, Populique in Principem, legitima postestate]. B.m.w. 1581 [1579].

J. Knox: The Appellation to the Nobility of and Estates [1558]. [w:] Idem: On Rebellion. Cambridge 2004.

J. Knox: Knox and Mary Queen of Scots [1561]. [w:] Idem: On Rebellion. Cambridge 2004.

Louis XIV: Instructions et lettres des Rois très-chretiens et de leurs ambassadeurs et autres actes concernant le concile de Trente. Paris 1654.

M. Luter: Büchlein von der babylonischen Gefängnis der Kirche. [w:] Idem: Die reformatischen Schriften. T. II. Darmstadt 1847. 
J. de Maistre: O papieżu. Kraków 1853 [1821].

J. de Mariana: Antologia. Madrid b.r.w.

J. Maritain: Primauté du Spirituel. Paris 1927.

F. Melanchton: De la puissance et authorité de la sainte eglise chretienne et comment elle peut etre cogneuё par la Parolle de Dieu [tyt. oryg.?]. B.m.w. 1543.

A. de Montreal: Le premier coup de retraité contre le tocsin sonné par la statue de Memnon. Contre le livre du Cardinal Ballarmin Jesuite. Montpellier 1611.

E. Le Noble de Tennelière: L'Esprit de Gerson ou instructions catholiques touchant le Saint Siège. B.m.w. 1691.

E. Pasquier: Catéchisme des Jésuites. Paris 1602.

A. Pighius: Hierarchiae ecclesiasticae assertio ad Paulum III libri sex. Coloniae 1551.

E. du Pin: Traité de la puissance ecclesiastique et temporelle. Paris 1707.

Pius V: Bulle 'Regnans in excelsis' [1570] . [w:] C. Mirbt: Quellen zur Geschichte des Papsttums und des römischen Katholizismus. Tübingen-Leipzig 1901.

A. de Richelieu: Oeuvres. Paris 1933.

J.J. Rousseau: Umowa społeczna. Poznań 1920 [1762].

A. Santarelli: Tractaus de haeresi, schismati, apostasia et de potestate romani Pontificis. Roma 1625.

E. Sieyès: Qu'est-ce que le Thiers-Etat? B.m.w. 1789.

Tomasz z Akwinu, Ptolemeusz z Lukki: O królowaniu. Królowi Cypru. Kraków 2006.

Tomasz z Akwinu: Summa Theologiae, na stronie internetowej corpusthomisiticum.org

S. Vigor: Quatre livres de l'Estat et gouvernement de l'Eglise. Troyes 1622.

F. Vitoria: Leçons sur les Indiens et sur le droit de guerre [De Indis]. Genève 1966 [1532].

\section{Opracowania:}

G. Alberigo: The Conciliar Church. [w:] T.M. Izbicki, C.M. Bellito (red.): The Church, the Councils and the Reform. The Legacy of the Fifteenth Century. Pittsboro 2008.

G. Alberigo: Ecclesiologia del Concilio di Trento, „Rivista di Storia della Chiesa in Italia“, 1964, nr 18.

G. Alberigo: Lo sviluppo della dottrina sui poteri nella Chiesa universale. Momenti essenziali tra il XVI e il XIX secolo. Roma 1964.

A.M.D.G.: Święty Robert Bellarmin T.J. Kraków 1930.

F.X. Arnold: Die Staatslehre des Kardinals Bellarmin. Ein Beitrag zur Rechts- und Staatsphilosophie des konfessionellen Zeitalters. München 1934.

H.-X. Arquillière: L'Augustinisme politique. Essai sur la formation des théories politiques du MoyenAge. Paris 1972.

P.A. van den Baar: Die kirchliche Lehre der Translatio Imperii Romani bis zur Mitte des 13. Jahrhunderts. Romae 1956. 
X.-M. Le Bachelet: Bellarmin à Index. Documents nouveaux, „Etudes”, 1907, nr 44.

P. Badillo O’Farrell: Retorno al tacitismo y la Razón de Estado. [w:] Ibidem, M.A. Pastor Pérez (red.): Tácito y tacitismo en España. Barcelona 2013.

J. Barthas: Formes de gouvernement ou modalités de la preuve? Eclaircissements sur le 'Traité du tyran' de Bartole da Sasseferato. [w:] Idem (red.): Della tirania: Machiavelli con Bartolo. Firenze 2007.

J. Bartelson: A Genealogy of Sovereignty. Cambridge 1996.

J. Basista: Propaganda religijna w przededniu i pierwszych latach angielskiej wojny domowej. Kraków 2007.

J. Baszkiewicz: Myśl polityczna wieków średnich. Poznań 1998.

J. Baszkiewicz: Państwo, rewolucja, kultura polityczna. Poznań 2009.

J. Baszkiewicz: Państwo suwerenne w feudalnej doktrynie politycznej do początku XIV wieku. Warszawa 1964.

J. Beumer: Die Frage nach Schrift und Tradition bei Robert Bellarmin, „Schol“, 1959, nr 34.

R. Bireley: The Refashioning of Catholicism, 1450-1700. Washington 1999.

A. Black: Monarchy and Community. Political Ideas in the Later Conciliar Controversy, 1430-1450. Cambridge 1970.

B. Bourdin: La genèse théologico-politique de l'Etat moderne: la controverse de Jacques Ier d'Angleterre avec le cardinal Bellarmin. Paris 2004.

P. Bourdin: La théologie politique de saint Thomas. [w:] Ch. Zarka (red.): Aspects de la pensée médiévale dans la philosophie politique moderne. Paris 1999.

A. Boureau: La religion de l'Etat. La construction de la République étatique dans le discours théologique de l'Occident médiéval (1250-1350). Paris 2006.

K. Brandi: Deutche Geschichte im Zeitler der Reformation und Gegenreformation. Leipzig 1941.

J. Brodrick: Robert Bellarmin. L’humaniste et le saint. Bruges 1963.

O. de la Brosse: Le Pape et le concile. La comparaison de leurs pouvoirs à la veille de la Réforme. Paris 1965.

W. Buchner: Wojna i konkwista. Hiszpańska myśl polityczna Złotego Wieku. Kraków 2007.

F. Calasso: I glossatori e la teoria della sovrenità. Milano 1951.

R.W. Carlyle, A.J. Carlyle: History of mediaeval political Theory. T. II. Edinburgh 1903-50.

F. Carpintero Benitez: Del derecho natural medieval al derecho natural moderno: Fernando Vazquez de Menchaca. Salamanca 1977.

P. Castañeda Delgado: La Teocracia pontifical y la conquista de America. Vitoria 1968.

F.P. Cavanan: Subordination of the State to the Church according to Suarez, "Theological Studies", 1951, nr 12.

L. Cedroni: La comunità perfecta. Il pensiero politico di Francisco Suárez. Roma 1996. 
V. Chaffour-Kestner: Etudes sur les réformateurs du XVIe siècle. T. I. Paris 1853.

A.A. Chafuen: Wiara i wolność. Myśl ekonomiczna późnych scholastyków. Warszawa 2007.

A. Couartou: La souveraineté populaire chez Francisco Suarez. Bordeaux 1974.

O. Dann: Nation und Nationalismus in Deutschland 1770-1990. München 1996.

M. David: La souveraineté et les limites juridiques du pouvoir monarchique du XIe au XVe siècle. Paris 1954.

M. Davies: Sobór Watykański II a wolność religijna. Warszawa 2002.

E. Fabbri: Roberto Bellarmino e Thomas Hobbes. Teologie politiche a confronto. Roma 2009.

J.A. Fernandez-Santamaria: Razon de Estado y politica en el pensamiento español del Barroco (15951640). Madrid 1986.

J.A. Fernandez-Santamaria: The State, War and Peace. Spanish Political Thought in the Renaissance, 1516-1559. Cambridge 1997.

D. Ferraro: Tradizione e ragione in Juan de Mariana. Milano 1989.

H.-R. Feugueray: Essai sur les doctrines politiques de Saint Thomas d'Aquin. Paris 1857.

J.N. Figgis: The Divine Right of Kinges. New York 1965.

J.N. Figgis: Political Thought from Gerson to Grotius: 1414-1625. Kitchener 1999.

V. Frajese: Una teoria della censura: Bellarmino e il potere indiretto dei papi, „Studi Storici”, 1984.

J.M. Gallegos Rocafull: La Doctrína Política del P. Francisco Suárez. Mexico 1948.

K. Ganzer: Gallikanische und römische Primatauffassung in Wiederstreit. Zudem ekklesiologischen Auseinandersetzungen auf dem Konzil von Trient, „Historisches Jahrbuch“, 1989, nr 109.

M. Garcia-Pelayo: Frederico II de Suábia e o nascimento do estado moderno. Minas Gerais 1961.

M. Garcia-Pelayo: El Reino de Dios. Arquetipo politico. Madrid 1959.

G. Glez: Pouvoir du pape dans l'ordre temporel. [w:] A. Vacant, E. Mangenot (red.): Dictionnaire de théologie catholique. T. XII/2. Paris 1935.

I. Gómez Robledo: El origen del poder político según Francisco Suárez. Mexico 1998.

M. Grabmann: Die echten Schriften des hl. Thomas von Aquin. München 1920.

O. Hageneder: Kirche und Christenheit in der neuen Ekklesiologie des Papsttums. [w:] G. Andenna (red.): Pensiero e sperimentazioni istituzionali nella „Societas Christiana” (1040-1250). Milano 2007.

O. Hageneder: Il Sole e la Luna. Papato, imperio e regni nella teoria e nella prassi dei secoli XII e XIII. Milano 2000.

B. Hamilton: Political Thought in Sixteenth-Century Spain. A Study of political Ideas of Vitoria, de Soto, Suárez, and Molina. Oxford 1963.

Ch. Hansen Roses: Ensayo sobre el pensamiento político del padre Juan de Mariana. Santiago 1959.

C.J.H. Hayes: Essays on Nationalism. New York 1933. 
C. Hermann: Papisme et national-catholicisme espagnols, mi-XVe/mi-XVII siècle, "Bulletin de la Société d'Histoire Moderne et Contemporaine”, 2000, nr 3-4.

H. Höpfl: Jesuit Political Thought. The Society of Jesus and the State, c. 1540-1630. New York 2004.

U. Horst: Papst - Konzil - Unfehlbarkeit. Die Ekklesiologie der Summenkommentare von Cajetan bis Billuart. Mainz 1978.

N. Iung: Alvaro Pelayo - évêque et pénitencier de Jean XXII. Un Franciscain, théologien de pouvoir pontifical au XIVe siècle. Paris 1931.

A. Jouanna: Le prince absolu. Apogée et déclin de l'imaginaire monarchique. Paris 2014.

E. Kantorowicz: Frederick the Second, 1194-1250. New York 1957.

F. Kempf: Papsttum und Kaisertum bei Innocenz III. Die geistigen und rechtlichen Grundlagen seiner Thronstreitpolitik. Roma 1954.

G. de Lagarde: La naissance de l'ésprit laïque au déclin du Moyen Age. T. I. Paris 1942.

P. Lake: The significance of the Elizabethan identification of the Pope as Antichrist, "Journal of Ecclesiastical History", 1980, nr 31.

J. Lecler: L'Eglise et la souveraineté de l'Etat. Paris 1944.

H. de Lubac: Le pouvoir de l'Eglise en matière temporelle, „Revue des Sciences Religieuses“, 1932, nr 12.

A. Luchaire: Innocent III. La Papauté et l'Empire. Paris 1906.

M. Maccarrone: Chiesa e stato nella dottrina di papa Innocenzo III. Romae 1940.

M. Maccarrone: La papauté et Philippe Auguste. Le décrétale ,Novit ille. [w:] R.H. Bautier (red.): La France de Philippe Auguste. Le Temps des Mutations. Paris 1982.

M. Maccarrone: Studi su Innocenze III. Padova 1972.

J.-A. Maravall: La philosophie politique espagnole au XVIIe siècle dans ses rapports avec l'ésprit de la contre-réforme. Paris 1955.

U. Mariani: Chiesa e Stato nei theologi agostiniani del secolo XIV. Roma 1957.

A. Marongiù: Ein ,Modellstaat' im italienischer Mittelalter. Das normannisch-staufische Reich in Sizilien. [w:] G. Wolf (red.): Stupor Mundi. Zur Geschichte Friedrichs II. von Hohenstaufen. Darmstadt 1982.

A.-G. Martimort: Le gallicanisme de Bossuet. Paris 1953.

V. Martin: Le Gallicanisme et la Réforme catholique. Essai historique sur l'introduction en France des décrets du Concile de Trente (1563-1615). Paris 1919.

E. Maschke: Die Wirtschaftspolitik Kaiser Friedrichs II im Könichreich Sizilien. [w:] G. Wolf (red.): Stupor Mundi. Zur Geschichte Friedrichs II. von Hohenstaufen. Darmstadt 1982.

S. Mastellone: Tomasso Bozio, teorico dell’ordine ecclesiastico, „Il Pensiero Politico“, 1980, nr 13. 
R. de Mattei: Il pensiero politico italiano nell'età della Controriforma. T. I-II. Napoli 1982.

A. Milton: Catholic and Reformed. The Roman and Protestant Churches in English Protestant Thought, 1600-1640. Cambridge 2002.

S. Mochi Onory: Il tramonto della sovranità imperiale, "Rivista di Storia del Diritto Italiano", 1951, nr 24.

J. Morais Barbosa: O 'De Statu et planctu ecclesiae’. Estudio critico. Lisboa 1982.

J.B. Morall: Political Thought in medieval Times. Toronto 1980.

F. Motta: Bellarmino. Una teologia politica della Controriforma. Brescia 2005.

F. Moulart: L'Eglise et l'Etat. Paris 1887.

H. Münkler: Mity Niemców. Warszawa 2013.

J.C. Murray: St. Robert Bellarmin on the indirect Power, “Theological Studies", 1948, nr 9.

E. Naszalyi: El Estado segun Francisco de Vitoria. Madrid 1948.

F. Nourisson: La politique de Bossuet. Paris 1867.

J.L. Orella Unzue: Il concetto di impero romano e il problema della 'translatio' nella polemica tra Flacio Illirico e Bellarmino. [w:] Roma, Costantinopoli, Mosca. Napoli 1983.

M. Pacaut: Alexandre III. Etude sur la conception du pouvoir pontifical dans sa pensée et dans son oeuvre. Paris 1956.

M. Pacaut: L’autorité pontificale selon Innocent IV, “Le Moyen Age”, 1960, nr 15.

M. Pacaut: La Théocratie. L'Eglise et le pouvoir au Moyen Age. Paris 1957.

S. Panizo Orallo: Persona juridica y ficción. Estudio de la obra de Sinibaldo de Feischi (Inocencio IV). Pamplona 1975.

J. Pegon: Episcopat et hierarchie du Concile de Trente, „Nouvelle Revue Théologique”, 1960, nr 92.

J. Peña Echeverría: Estudio preliminar. [w:] Idem (red.): La razón de Estado en España. Siglos XVIXVII (Antología de textos), Madrid 1988.

L. Pereña Vicente: Diego de Covarrubis y Leyra. Maestro de derecho internacional. Madrid 1957.

E.M. Peters: Rex inutilis. Sancho II of Portugal and thirteenth century Deposition Theory, "Studia Gratiana”, 1967, nr 14.

E.M. Peters: The Shadow King. Rex Inutilis im Medieval Law and Literature. London 1970.

I. Popiuk-Rysińska: Suwerenność w rozwoju stosunków międzynarodowych. Warszawa 1993.

G. Post: The Theory of public Law and the State in the thirteenth Century, "Seminar", 1948, nr 6.

A. Prieto Prieto: Inocencio III y el Sacro-Romano Imperio. Leon 1982.

P. Prodi: La sovranità temporale dei Papi e il Concilio di Trento. [w:] Ibidem, H. Jednin (red.): Il Concilio di Trento come crocevia della politica europea. Bologna 1979.

P. Prodi: Il sovrano pontefice. Un corpo e due anime: la monarchia papale nella prima età moderna. Bologna 1982. 
D. Quaglioni: Politica e diritto nel Trecento Italiano. Il 'De Tyranno' di Bartolo da Sassoferrato (13141357). Città di Castello 1983.

R.H.W. Regout: La doctrine de la guerre juste d’après les théologiens et canonistes catholiques. Aalen 1974. W. Reinhard: Reformation, Counter-Reformation and the Early Modern State: A Reassessment. [w:] D.M. Luebke (red.): The Counter-Reformation. Malden 2005.

A. Richardt: Saint Robert Bellarmin. Le défenseur de la foi, 1542-1621. Paris 2004.

F. De los Rios: Religion y Estado en la España del siglo XVI. Mexico 1957.

A. Rivera-Damas: Pensamiento politico de Hostiensis. Estudio juridico-histórico sobre las relaciones entre el Sacerdocio y el Imperio en los escritos de Enrique de Susa. Zürich 1964.

J. Rivière: Le Problème de l'Eglise et de l'Etat au temps de Philippe Le Bel. Louvain-Paris 1926.

F. Rocquain: La Papauté du Moyen Age. Nicolas Ier, Grégoire VII, Innocent III, Boniface VIII. Etudes sur le pouvoir pontifical. Paris 1881.

H. Rommen: La teoria del Estado y de la communidad internacional en Francisco Suarez. Buenos Aires 1951.

A.M. Ruoco Varela: Estado e Iglesia en la España del siglo XVI. Madrid 2001.

K. Schatz: Prymat papieski od początków do współczesności. Kraków 2004.

A. Schubert: Bellarmin und die lutherische Ekklesiologie des Konfessionellen Zeitalters, „Evangelische Theologie“, 2015, nr 75.

H. Schulze: Staat und Nation in der europäischen Geschichte. München 1999.

H. Quaritsch: Souveränität. Entstehung und Entwicklung des Begriffs in Frankreich und Deutschland vom 13. Jahrhundert bis 1806. Berlin 1986.

L. Sanchez Agesta: El concepto del Estado en el pensamiento español del siglo XVI. Madrid 1959.

C.N. Sidney Woolf: Bartolus of Sassoferato. His Position in the History of medieval political Thought. Cambridge 1913.

Q. Skinner: The Foundations of Modern Political Thought. T. II. New York 1998.

Q. Skinner: The State. [w:] T. Ball, J. Farr, R.L. Hanson (red.): Politicial Innovation and Conceptual Change. Cambridge 1989.

J. Soder: Francisco Suárez und das Völkerrecht. Grundgedanken zu Staat, Recht und internationale Beziehungen. Frankfurt am Main 1973.

E. Thuau: Raison d'Etat et pensée politique à l'époque de Richelieu. Paris 2000.

B. Töpfer: Tendenzen zur Entsakralisierung der Herrscherswürde in der Zeit des Investiturstreits, „Jahrbuch für Geschichte des Feudalismus“, 1982, nr 6.

G. Toffanini: Machiavelli e il 'Tacitismo'. La 'Politica storica' al tempo della contrariforma. Napoli 1972.

W. Ullmann: The Development of the medieval Idea of Sovereignty, "The English Historical Review”, 1949 , nr 1. 
W. Ullmann: The Growth of papal Government in the Middle Ages. A Study in the ideological Relation of clerical to lay Power. London 1962.

W. Ullmann: Leo I and the theme of papal primacy, „Journal of Theological Studies”, 1960, nr 11.

W. Ullmann: Medieval Papalizm. The Political Theories of the Medieval Canonists. London 1949.

S. Vacca: Prima sedes a nemine iudicatur. Genesi e sviluppo storico dell'assioma fin al Decreto di Graziano. Roma 1993.

A. Vanderpol: La doctrine scholastique de droit de guerre. Paris 1925.

E. Voegelin: The Later Middle Ages. [w:] Idem: The Collected Works. T. XXI. Columbia 1998.

E. Voegelin: Die Politischen Religionen. München 2007.

A.W. Ward: The Counter Reformation. London 1889.

J.A. Watt: The Theory of papal Monarchy in the Thirteenth Century. The Contribution of the Canonists. New York 1965.

H. Weber: Laccettazione in Francia del Concilio di Trento. [w:] P. Prodi, H. Jednin (red.): Il Concilio di Trento come crocevia della politica europea. Bologna 1979.

H.-U. Wehler: Nationalismus. Geschichte, Formen, Folgen. München 2001.

A. Wielomski: Kościół w cieniu gilotyny. Katolicyzm francuski wobec Rewolucji (1789-1815). Warszawa 2009.

A. Wielomski: Myśl polityczna Reformacji i Kontrreformacji. T. I. Rewolucja protestancka. Warszawa 2013.

A. Wielomski: Teokracja papieska 1073-1378. Myśl polityczna papieży, papalistów i ich przeciwników. Warszawa 2011.

M. Wilks: The Problem of Sovereignty in the Later Middle Ages: the Papal Monarchy. Cambridge 1963.

D. Wyduckel: Princeps legibus solutus. Eine Untersuchung zur frühmodernen Rechts- und Staatslehre. Berlin 1979. 